\title{
SEP-363856, a Novel Psychotropic Agent with a Unique, Non-D 2 Receptor Mechanism of Action ${ }^{[}$
}

\author{
Nina Dedic, ${ }^{1}$ Philip G. Jones, ${ }^{1}$ Seth C. Hopkins, Robert Lew, Liming Shao, \\ John E. Campbell, Kerry L. Spear, Thomas H. Large, Una C. Campbell, Taleen Hanania, \\ Emer Leahy, and Kenneth S. Koblan \\ Sunovion Pharmaceuticals, Marlborough, Massachusetts (N.D., P.G.J., S.C.H., R.L., L.S., J.E.C., K.L.S., T.H.L., U.C.C., K.S.K.); \\ and PsychoGenics, Paramus, New Jersey (T.H., E.L.)
}

Received May 24, 2019; accepted July 10, 2019

\begin{abstract}
For the past 50 years, the clinical efficacy of antipsychotic medications has relied on blockade of dopamine $D_{2}$ receptors. Drug development of non- $\mathrm{D}_{2}$ compounds, seeking to avoid the limiting side effects of dopamine receptor blockade, has failed to date to yield new medicines for patients. In this work, we report the discovery of SEP-363856 (SEP-856), a novel psychotropic agent with a unique mechanism of action. SEP-856 was discovered in a medicinal chemistry effort utilizing a high throughput, high content, mouse-behavior phenotyping platform, in combination with in vitro screening, aimed at developing non- $D_{2}$ (anti-target) compounds that could nevertheless retain efficacy across multiple animal models sensitive to $D_{2}$-based pharmacological mechanisms. SEP-856 demonstrated broad efficacy in putative rodent models relating to aspects of schizophrenia, including phencyclidine (PCP)-induced hyperactivity, prepulse inhibition, and PCP-induced deficits in social interaction. In addition to its favorable pharmacokinetic properties, lack of $D_{2}$ receptor occupancy, and the absence of catalepsy, SEP-856's broad profile was further highlighted by its robust suppression of rapid eye movement sleep in rats. Although the mechanism of action has not been fully elucidated, in vitro and in vivo pharmacology data as well as slice and in vivo electrophysiology recordings suggest that agonism at both trace
\end{abstract}

amine-associated receptor 1 and $5-\mathrm{HT}_{1 \mathrm{~A}}$ receptors is integral to its efficacy. Based on the preclinical data and its unique mechanism of action, SEP-856 is a promising new agent for the treatment of schizophrenia and represents a new pharmacological class expected to lack the side effects stemming from blockade of $D_{2}$ signaling.

\section{SIGNIFICANCE STATEMENT}

Since the discovery of chlorpromazine in the 1950s, the clinical efficacy of antipsychotic medications has relied on blockade of dopamine $D_{2}$ receptors, which is associated with substantial side effects and little to no efficacy in treating the negative and cognitive symptoms of schizophrenia. In this study, we describe the discovery and pharmacology of SEP-363856, a novel psychotropic agent that does not exert its antipsychotic-like effects through direct interaction with $D_{2}$ receptors. Although the mechanism of action has not been fully elucidated, our data suggest that agonism at both trace amine-associated receptor 1 and $5-\mathrm{HT}_{1 \mathrm{~A}}$ receptors is integral to its efficacy. Based on its unique profile in preclinical species, SEP-363856 represents a promising candidate for the treatment of schizophrenia and potentially other neuropsychiatric disorders.

\section{Introduction}

Schizophrenia is a chronic and disabling psychiatric disorder that affects approximately $1 \%$ of the global population. It is characterized by positive symptoms (e.g., hallucinations, delusions, and thought disorders), negative symptoms (e.g., flat affect, anhedonia, alogia, and avolition), and cognitive deficits (e.g., impaired memory, attention, and executive functioning). Despite advances in our understanding of the

At the time these studies were conducted, all authors were employees of either Sunovion Pharmaceuticals or PsychoGenics. Some authors are inventors on patents related to the subject matter.

${ }^{1}$ N.D. and P.G.J. contributed equally to the work.

https://doi.org/10.1124/jpet.119.260281.

S This article has supplemental material available at jpet.aspetjournals.org. pathophysiology, schizophrenia remains one of the most challenging diseases to treat due to the diversity of clinical symptoms, the heterogeneity of clinical response, the side effects of current treatments, and its association with high morbidity and mortality (Insel, 2010; Meyer-Lindenberg, 2010; Girgis et al., 2019).

Antipsychotics have been the standard of care for schizophrenia since the discovery of chlorpromazine in the $1950 \mathrm{~s}$ (Charpentier et al., 1952; Laborit et al., 1952; Lehmann and Ban, 1997). Since then, numerous new antipsychotics have been launched, but they have essentially the same mechanism of action, mediating their efficacy against the positive symptoms through antagonism of dopamine $\mathrm{D}_{2}$ and/or serotonin $5-\mathrm{HT}_{2 \mathrm{~A}}$ receptors. Although improvements in drug safety have been made, a focus on the same molecular targets has

ABBREVIATIONS: CNS, central nervous system; DRN, dorsal raphe nucleus; EEG, electroencephalogram; EPS, extrapyramidal symptoms; FST, forced swim test; KO, knockout; MOA, mechanism of action; PCP, phencyclidine; PPI, prepulse inhibition; REM, rapid eye movement; TAAR1, trace amine-associated receptor 1 ; Tb, body temperature; VTA, ventral tegmental area. 
not led to improved efficacy (Lieberman et al., 2005; Girgis et al., 2019). In fact, the negative and cognitive symptoms remain largely untreated by currently available antipsychotics. Furthermore, approximately $30 \%$ of patients have treatment-resistant schizophrenia (Samara et al., 2016). The urgency for new treatments is therefore apparent.

More recently, drug development efforts have focused on molecular targets other than $\mathrm{D}_{2}$ and $5-\mathrm{HT}_{2 \mathrm{~A}}$ receptors, including GlyT1, $\mathrm{D}_{1}, \mathrm{D}_{4}, \mathrm{D}_{3}$, N-methyl-D-aspartate (NMDA), mGluR2/3, $\alpha$-amino-3-hydroxy-5-methyl-4-isoxazolepropionic acid (AMPA), 5- $\mathrm{HT}_{2 \mathrm{C}}$, nicotinic $\alpha 7$, muscarinic $\mathrm{M}_{1} / \mathrm{M}_{4}, \mathrm{H}_{3}, \mathrm{NK}-3$, and $\sigma$ receptors (Miyamoto et al., 2000; Karam et al., 2010; Girgis et al., 2019). However, despite promising efficacy in preclinical models for many of these targets, most novel, non- $\mathrm{D}_{2} / 5-\mathrm{HT}_{2 \mathrm{~A}}$ mechanisms have shown limited or no success in clinical trials (Girgis et al., 2019). Thus, it is crucial to pursue alternative strategies for novel drug development for schizophrenia.

Traditional drug discovery efforts have been focused on designing compounds with high selectivity and potency for a target protein of interest. Unfortunately, in psychiatry there are few validated drug targets, in part due to the complexity of the disorders, rendering this approach largely unsuccessful. Phenotypic drug discovery does not require any knowledge of a molecular target(s) associated with a disease and has been associated with the discovery of first-in-class medications (Swinney and Anthony, 2011; Moffat et al., 2017). Examples include most anticonvulsants as well as antiviral drugs such as daclatasvir, which was discovered using a cell-based phenotypic screen (Belema and Meanwell, 2014). An in vivo phenotypic drug discovery approach could be particularly valuable for the discovery of new therapeutics for psychiatric indications that have a complex underlying pathophysiology and where polypharmacology is common and likely necessary for clinical efficacy. However, the selection of an appropriate target combination and the design of a safe and efficacious polypharmacological molecule are extremely difficult. We therefore took a targetagnostic in vivo approach by utilizing a mouse behavioral platform (Roberds et al., 2011; Alexandrov et al., 2015; Shao et al., 2016) together with anti-target in vitro screening to identify antipsychotic-like compounds that don't exert their effects through direct modulation of $\mathrm{D}_{2}$ or $5-\mathrm{HT}_{2 \mathrm{~A}}$ receptors.

In this work, we report the discovery of SEP-363856 (SEP856), a novel psychotropic agent with a unique, non- $\mathrm{D}_{2} / 5-\mathrm{HT}_{2 \mathrm{~A}}$ mechanism of action. SEP-856 exhibits antipsychotic-like efficacy in vivo and demonstrates the potential for treating the positive and negative symptoms of schizophrenia. Although the mechanism of action has not been fully elucidated, in vitro and in vivo pharmacology data suggest that agonism at both trace amine-associated receptor 1 (TAAR1) and 5$\mathrm{HT}_{1 \mathrm{~A}}$ receptors is integral to its efficacy. The data presented in this work suggest that SEP-856 may have broad therapeutic efficacy in schizophrenia and potentially other psychiatric disorders.

\section{Materials and Methods}

Animals. Adult male C57BL/6J mice were utilized for behavioral screening, phencyclidine (PCP)-induced hyperactivity, catalepsy, and prepulse inhibition (PPI) studies, as well as patch-clamp recordings. The forced swim test (FST) was performed in adult male BalbC/J mice. Adult male Sprague-Dawley rats were utilized for electroencephalogram (EEG) recordings, microdialysis, in vivo cellular recordings, autoradiography, and PCP-induced deficits in social interaction.
In vivo assessment of $\mathrm{D}_{2}$ occupancy of SEP-856 was performed in nonhuman primate female baboons (Papio anubis). In vivo pharmacokinetic studies were performed in male adult ICR mice, adult male Sprague-Dawley rats, and male rhesus macaques (Macaca mulatta). Animals were maintained on a 12/12 light/dark cycle. The room temperature was maintained between $20^{\circ} \mathrm{C}$ and $23^{\circ} \mathrm{C}$ with a relative humidity maintained between $30 \%$ and $70 \%$. Chow and water were provided ad libitum for the duration of the studies, unless otherwise stated. Animals were randomly assigned across treatment groups and studies conducted with experimenters blinded to the drug treatment. Further details (e.g., vendor, age, and/or weight range) are provided in the Supplemental Material.

All animal studies were conducted in accordance with the institutional animal care protocols complying with federal regulations and were approved by the respective Institutional Animal Care and Use Committees.

Test Compounds. Haloperidol, risperidone, quetiapine, clozapine, sertraline, PCP, 8-OH-DPAT, and WAY-100635 were purchased from Sigma-Aldrich. SEP-363856 [(S)-1-(4,7-dihydro-5H-thieno[2,3-c] pyran-7-yl)- $N$-methylmethanamine hydrochloride] and its enantiomer SEP-363855 were synthesized by Sunovion Pharmaceuticals, and all doses were corrected for salt content. Further information regarding formulation for each study is provided in the Supplemental Material.

Behavior-Based, Mouse Phenotypic Screening. The central nervous system (CNS) properties of SEP-856 were evaluated using the SmartCube ${ }^{\circledR}$ system, a high-throughput, automated mouse behavioral platform (Roberds et al., 2011; Alexandrov et al., 2015; Shao et al., 2016). Further experimental details are provided in the Supplemental Material.

Behavioral Phenotyping. Details on PPI, PCP-induced hyperactivity, catalepsy, FST, and PCP-induced deficits in social interaction are provided in the Supplemental Material.

EEG Recordings. EEG recordings were performed in seven adult male Sprague-Dawley rats using a crossover design. Animals were implanted with chronic recording devices for continuous recordings of electroencephalograph (EEG), electromyograph, core body temperature (Tb), and locomotor activity via telemetry (DQ ART 4.1 software; Data Sciences, St. Paul, MN). Following completion of the data collection, expert scorers determined states of sleep and wakefulness in 10-second epochs by examining the recordings visually using NeuroScore software (Data Sciences). All doses of SEP-856, caffeine, and vehicle were administered by oral gavage. A minimum of 3 days elapsed between doses. To evaluate the effects of SEP-856 on sleep/ wake parameters during the inactive period, dosing occurred during the middle of the rats' normal inactive period. The first 6 hours of the recording were scored and analyzed. For additional details, please refer to the Supplemental Material.

In Vivo Microdialysis. Extracellular dopamine and serotonin levels were assessed in the prefrontal cortex and dorsal striatum using in vivo microdialysis in freely moving Sprague-Dawley rats. For detailed methods, please refer to the Supplemental Material.

In Vivo Pharmacokinetics Studies. Details on in vivo pharmacokinetic measurements are provided in the Supplemental Material.

In Vitro and In Vivo 5-HT $\mathbf{H A}_{1 \mathrm{~A}}$ and $\mathrm{D}_{\mathbf{2}}$ Receptor Occupancy Studies. In vitro autoradiography was used to determine the effects of SEP-856 on $\left[{ }^{3} \mathrm{H}\right]-8-\mathrm{OH}-\mathrm{DPAT}$ binding to 5 - $\mathrm{HT}_{1 \mathrm{~A}}$ receptors in rat brain sections. In vivo occupancy of SEP-856 at $\mathrm{D}_{2}$ receptors was measured with $\left[{ }^{3} \mathrm{H}\right]$-raclopride in Sprague-Dawley rats and with $\left[{ }^{18} \mathrm{~F}\right]$ fallypride-positron emission tomography in nonhuman primates (Papio anubis). For details, refer to Supplemental Material.

Patch-Clamp Recordings in the Dorsal Raphe Nucleus and Ventral Tegmental Area. In vitro whole-cell patch-clamp recording techniques were used in isolated slice preparations (male C57BL/ 6J mice, 4-16 weeks) of the dorsal raphe nucleus (DRN) and ventral tegmental area (VTA) to investigate the effects of SEP-856 on neuronal activity. The experiments examined the effects of SEP-856 $(1-30 \mu \mathrm{M})$ on the activity of DRN and VTA neurons that were 
characterized by their electrophysiological properties and/or their sensitivity to application of the $5-\mathrm{HT}_{1 \mathrm{~A}}$ receptor agonist $8-\mathrm{OH}$ DPAT (DPAT; $10 \mu \mathrm{M}$ ). Subsequently, effects mediated via the TAAR1 and/or via the $5-\mathrm{HT}_{1 \mathrm{~A}}$ receptor were investigated using the selective antagonist N-(3-Ethoxy-phenyl)-4-pyrrolidin-1-yl-3-trifluoromethyl-benzamide (EPPTB; 0.05-1 $\mu \mathrm{M}$ ) and the selective antagonist WAY-100635 (WAY-635; $10 \mu \mathrm{M}$ ), respectively. All compounds were dissolved in either DMSO or $\mathrm{ddH}_{2} \mathrm{O}$ and diluted with artificial cerebrospinal fluid (aCSF) to a final concentration from a minimum 1000 -fold higher stock concentration (maximum slice DMSO concentration $0.1 \%$ ). Whole-cell patch-clamp recordings were performed at room temperature using the blind version of the patch-clamp technique with either Axopatch 1D or Multiclamp 700B amplifiers. For detailed methods, refer to the Supplemental Material.

In Vivo Extracellular Single-Unit Recordings in the DRN. In vivo extracellular single-unit recordings were used to characterize the effects of SEP-856 on firing of DRN neurons in anesthetized, male Sprague-Dawley rats. Following surgery and insertion of the recording electrode, baseline firing activity of the neuron was recorded for at least 10 minutes prior to the compound administration. SEP-856 was tested at 1,2 , and $5 \mathrm{mg} / \mathrm{kg}$ by i.v. injection. After clear inhibitory effects were observed (3-5 minutes after compound administration), WAY-100635 (80 $\mu \mathrm{g} / \mathrm{kg}$, i.v.) was given to determine whether it could antagonize the inhibitory effect of SEP-856. Blood samples were taken 30 minutes following compound administration. For additional details, refer to the Supplemental Material.

In Vitro Pharmacology. The in vitro pharmacology of SEP-856 at known receptors and enzymes was assessed in broad panel screens (Eurofins CEREP SA, Celle-Lévescault, France; Ricerca, Taipei, Taiwan). For those targets at which SEP-856 (10 $\mu \mathrm{M})$ demonstrated greater than $50 \%$ inhibition, dose-response curves were generated and inhibitory constant values were determined.
Incubation conditions and additional details for equilibrium radioligand binding are listed in the Supplemental Material.

The functional (both agonist and antagonist) effects were also determined. Assays used to study the functional effects were as follows: Intracellular cAMP levels were determined for $5-\mathrm{HT}_{1 \mathrm{~A}}, 5$ $\mathrm{HT}_{7}$, TAAR1, and $\mathrm{D}_{2}$, using either the DiscoveRx HitHunter cAMP $\mathrm{XS}^{+}$assay or the Cisbio Homogenous Time-Resolved Fluorescence (HTRF) cAMP assay. The $5-\mathrm{HT}_{1 \mathrm{~A}}$ was also studied using GTP $\gamma \mathrm{S}$ binding. Impedance was used for $5-\mathrm{HT}_{1 \mathrm{~B}}, 5-\mathrm{HT}_{1 \mathrm{D}}$, and $\alpha_{2 \mathrm{~A}}$. Intracellular $\mathrm{Ca}^{2+}$ release was used for $5-\mathrm{HT}_{2 \mathrm{~A}}$ and $5-\mathrm{HT}_{2 \mathrm{C}}$. Inositol monophosphate $\left(\mathrm{IP}_{1}\right)$ accumulation was used for $5-\mathrm{HT}_{2 \mathrm{~B}}$. $\mathrm{D}_{2}$ was also studied using the DiscoveRx PathHunter $\beta$-arrestin recruitment assay.

Statistical Analyses. Statistical analyses were performed using the commercially available software GraphPad Prism v6.0, unless otherwise noted. Results are either presented as mean \pm S.E.M. or mean \pm S.D. (for pharmacokinetics (PK) analyses). Simple comparisons were evaluated with two-tailed, Student's $t$ test. Multiple group comparisons were assessed with one-way ANOVA, followed by appropriate post hoc analyses. Time-dependent measures were assessed with repeated measures ANOVA followed by appropriate post hoc analyses. Statistical significance was defined as $P<0.05$.

\section{Results}

SEP-856 Exhibits Antipsychotic-Like Activity in the Smartcube System. SEP-856 (Fig. 1A) was identified during a medicinal chemistry program designed to develop structurally and mechanistically novel antipsychotics using in vivo mouse phenotypic screening in combination with comprehensive in vitro and in vivo molecular profiling.
A<smiles>CNC[C@H]1OCCc2ccsc21</smiles>

C

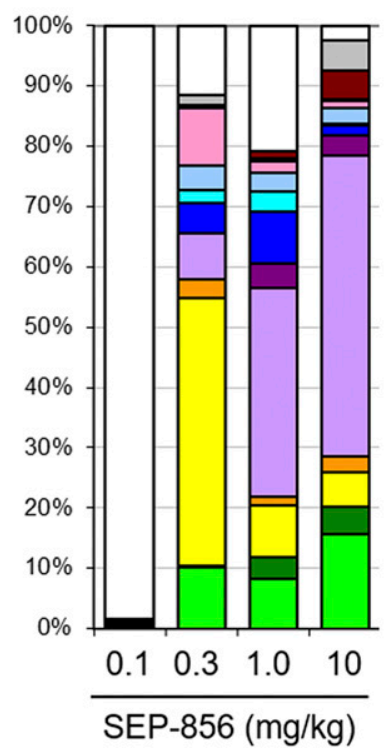

B

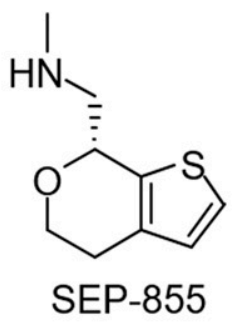

D

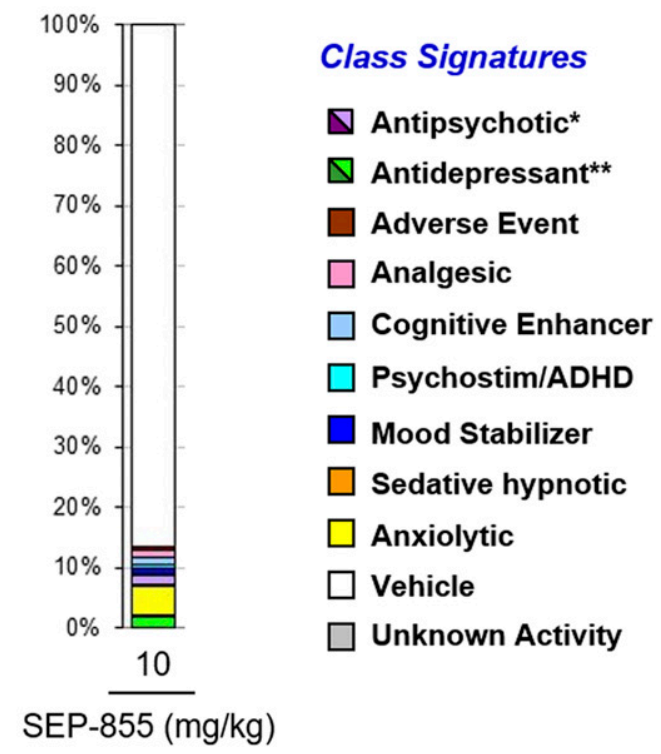

Fig. 1. SEP-856 exhibits a predominantly antipsychotic-like signature in SmartCube ${ }^{\circledR}$. The chemical structures of SEP-856 (A) and its enantiomer SEP-855 (B). The behavioral signature of SEP-856 (C) includes anxiolytic (yellow) and antipsychotic (purple) components. In contrast, its enantiomer SEP-855 is largely behaviorally inactive in mice, represented by the vehicle-like white bar (D). The behavioral platform was established and validated with marketed CNS drugs, producing a library of drug-class signatures. (E) Each of the 15 classes is represented by a different color, as indicated [*antipsychotic (purple) and high-dose antipsychotic (dark purple); **antidepressant (green) and *high-dose antidepressant (dark green)]. $N=8-10$ mice/group. 
Screening was conducted during a 45-minute automated test session, in which mice were exposed to multiple challenges, and different behavioral domains were captured and analyzed using proprietary computer vision software and machine learning algorithms (Roberds et al., 2011; Alexandrov et al., 2015; Shao et al., 2016). The behavioral platform was established and validated with marketed CNS drugs, producing a library of drug-class signatures. Each class is represented by a different color; for example, purple and yellow indicate antipsychotic- and anxiolytic-like activity, respectively (Fig. 1E), and the behavioral activity is shown as a scale of $0 \%$ to $100 \%$. The data in Fig. 1C demonstrated that SEP-856 was behaviorally active at three of four doses tested $(0.3,1$, and $10 \mathrm{mg} / \mathrm{kg}$, i.p.). At $0.3 \mathrm{mg} / \mathrm{kg}$, SEP-856 was classified as an anxiolytic (represented by the primarily yellow color of the column) but showed a dose-dependent increase in an antipsychotic classification (purple), such that the signatures at 1 and $10 \mathrm{mg} / \mathrm{kg}$ were predominantly antipsychotic-like. As a comparison, the signatures of marketed antipsychotic drugs are shown in Supplemental Fig. 1. In addition, SEP-856 showed a modest antidepressant-like signal, illustrated by the green signal at $0.3,1$, and $10 \mathrm{mg} / \mathrm{kg}$. Overall, the results indicate that SEP-856 is CNS active and exhibits a behavioral signature similar to known antipsychotic drugs. Interestingly, its enantiomer, SEP-363855 (SEP-855), showed little behavioral activity at $10 \mathrm{mg} / \mathrm{kg}$ (i.p.), a dose at which SEP-856 was fully efficacious (Fig. 1, B and D).

In Vitro Pharmacology. To investigate the molecular targets mediating the response to SEP-856, the compound was tested against several panels of known molecular targets (ion channels, G protein-coupled receptors (GPCRs), and enzymes; Supplemental Tables 1-4). At $10 \mu \mathrm{M}$, SEP-856 showed $>50 \%$ inhibition of specific binding at $\alpha_{2 \mathrm{~A}}, \alpha_{2 \mathrm{~B}}, \mathrm{D}_{2}, 5-\mathrm{HT}_{1 \mathrm{~A}}$, $5-\mathrm{HT}_{1 \mathrm{~B}}, 5-\mathrm{HT}_{1 \mathrm{D}}, 5-\mathrm{HT}_{2 \mathrm{~A}}, 5-\mathrm{HT}_{2 \mathrm{~B}}, 5-\mathrm{HT}_{2 \mathrm{C}}$, and $5-\mathrm{HT}_{7}$ receptors. Inhibitory constant values are shown in Table 1 ranging from 0.031 to $21 \mu \mathrm{M}$. No significant activity of SEP-856 was observed at any of the enzymes studied (up to a concentration of $100 \mu \mathrm{M})$.

Receptor panel screening and follow-up functional testing showed that SEP-856 exhibited a range of activities at several receptors (Table 2). The most notable activity of SEP-856 was agonism at the human TAAR1 receptor $\left(\mathrm{EC}_{50}\right.$ of $0.14 \pm$ $0.062 \mu \mathrm{M}$, maximum efficacy $\left(\mathrm{E}_{\max }\right)=101.3 \% \pm 1.3 \%$ ) and the $5-\mathrm{HT}_{1 \mathrm{~A}}$ receptor $\left(\mathrm{EC}_{50}=2.3 \mu \mathrm{M}\right.$ with values ranging from 0.1 to $3 \mu \mathrm{M}, \mathrm{E}_{\max }=74.7 \% \pm 19.6 \%$; Fig. $\left.2 \mathrm{~B}\right)$. Interestingly,

\section{TABLE 1}

Receptor affinities.

Panel screens of up to 105 radioligand-binding assays and 34 enzyme assays were performed, and the affinity of SEP-856 was determined for receptors at which $>50 \%$ inhibition was seen at $10 \mu \mathrm{M}$. Details of radioligands, incubation conditions, and the targets in the screening panels are listed in the Supplemental Material. Data are shown as mean \pm S.E.M. $\left(n \geq 3, n=1\right.$ for $\left.5-\mathrm{HT}_{2 \mathrm{~B}}\right)$.

\begin{tabular}{lc}
\hline Receptor & $\mathrm{K}_{\mathrm{i}}(\mu \mathrm{M})$ \\
\hline $\mathrm{D}_{2 \mathrm{~s}}$ & $21.3 \pm 8.2$ \\
$5-\mathrm{HT}_{1 \mathrm{~A}}$ & $0.284 \pm 0.056$ \\
$5-\mathrm{HT}_{1 \mathrm{~B}}$ & $1.90 \pm 1.72$ \\
$5-\mathrm{HT}_{1 \mathrm{D}}$ & $1.13 \pm 0.21$ \\
$5-\mathrm{HT}_{2 \mathrm{~A}}$ & $17.25 \pm 4.0$ \\
$5-\mathrm{HT}_{2 \mathrm{~B}}$ & 1.1 \\
$5-\mathrm{HT}_{2 \mathrm{C}}$ & $2.45 \pm 0.82$ \\
$5-\mathrm{HT}_{7}$ & $0.031 \pm 0.003$ \\
$\alpha_{2 \mathrm{~A}}$ & $0.59 \pm 0.06$ \\
$\alpha_{2 \mathrm{~B}}$ & $1.9 \pm 0.10$ \\
\hline
\end{tabular}

activity at the human TAAR1 receptor demonstrated stereoselectivity in that SEP-855 (an enantiomer of SEP-856), which was inactive in the behavioral screening platform at $10 \mathrm{mg} / \mathrm{kg}$ (i.p.), had an $\mathrm{EC}_{50}$ of $1.7 \mu \mathrm{M}$ (Fig. 2A). In $\mathrm{D}_{2}$ receptor functional assays, SEP-856 exhibited weak partial agonism with $\mathrm{EC}_{50}$ values of $10.44 \pm 4 \mu \mathrm{M}\left(\mathrm{cAMP}, \mathrm{E}_{\max }=23.9 \% \pm\right.$ 7.6\%; Fig. 2C) and $8 \mu \mathrm{M}\left(\beta\right.$-arrestin recruitment, $\mathrm{E}_{\max }=$ $27.1 \%$ ). At $100 \mu \mathrm{M}, 34 \% \pm 1.16 \%$ inhibition was seen in the cAMP assay, and no antagonism was seen at concentrations up to $100 \mu \mathrm{M}$ in the $\beta$-arrestin recruitment assay. Low potency partial agonist activities were also observed at $5-\mathrm{HT}_{1 \mathrm{~B}}\left(\mathrm{EC}_{50}\right.$ $\left.=15.6 \pm 11.6 \mu \mathrm{M}, \mathrm{E}_{\max }=22.4 \% \pm 10.9 \%\right), 5-\mathrm{HT}_{1 \mathrm{D}}\left(\mathrm{EC}_{50}=\right.$ $\left.0.262 \pm 0.09 \mu \mathrm{M}, \mathrm{E}_{\max }=57.1 \% \pm 6.0 \%\right)$, and $5-\mathrm{HT}_{7}$ receptors $\left(\mathrm{EC}_{50}=6.7 \pm 1.32 \mu \mathrm{M}, \mathrm{E}_{\max }=41.0 \% \pm 9.5 \%\right)$. In a functional assay of $5-\mathrm{HT}_{2 \mathrm{~B}}$ activity, SEP-856 showed no agonism up to a concentration of $100 \mu \mathrm{M}$, whereas norfenfluramine, the positive control, was a full agonist with an $\mathrm{EC}_{50}$ value of $0.140 \mu \mathrm{M}$. Little to no activity was detected at the $5-\mathrm{HT}_{2 \mathrm{~A}}$ receptor, with $29.3 \%$ agonism seen only at the highest tested concentration of $10 \mu \mathrm{M}$.

SEP-856 Exhibits High Brain Penetrance and Good Systemic Bioavailability Following Oral Administration. Behavioral phenotypic screening demonstrated that SEP-856 is CNS active in mice following $0.3,1$, and $10 \mathrm{mg} / \mathrm{kg}$ intraperitoneal administration. Consequently, the pharmacokinetics of SEP-856 in plasma was characterized in ICR mice, Sprague-Dawley rats, and rhesus macaques following oral and/or i.v. dosing. Biologic samples were collected over 8 or 24 hours postdose. Brain exposure was also assessed in mice and rats following per os (p.o.) administration. SEP-856 was rapidly absorbed, with maximum plasma and brain concentrations reached within 0.25-0.5 hours in mice and rats and maximum plasma concentrations reached within $6 \pm 2.83$ hours in monkeys (Supplemental Table 5). SEP-856 penetrated mouse and rat brains after oral administration $(10 \mathrm{mg} / \mathrm{kg})$, with average brain-to-plasma area under the curve ratios of approximately3-4 (Supplemental Fig. 2). In addition, SEP-856 plasma and brain levels were still detectable at 8 hours postdose with fairly consistent brain/ plasma ratios over time. SEP-856's brain penetration and elimination pharmacokinetics as indicated by $t_{\max }$ and half life were similar to the plasma pharmacokinetics (Supplemental Table 5).

Oral bioavailability of SEP-856, determined by plasma area under the curve ratio after crossover oral and intravenous administrations, was high in rat and monkey with $58 \%$ to $120 \%$ and $\sim 71 \%$, respectively. Total plasma clearance of SEP856 was relatively high in rat $(5 \mathrm{mg} / \mathrm{kg}$, i.v.) and monkey ( $5 \mathrm{mg} / \mathrm{kg}$, i.v.) with 1.54 and $0.797 \mathrm{l} / \mathrm{h}$ per kilogram, respectively, and elimination half-lives of 1.2 and 3.1 hours, respectively.

SEP-856 Demonstrates Antipsychotic-Like Efficacy in Rodents. To demonstrate the antipsychotic-like profile of SEP-856, we performed a series of additional pharmacological studies that assess endophenotypes of schizophrenia and antidepressant efficacy in rodents.

Acute treatment with phencyclidine (PCP), which induces robust hyperactivity in rodents and psychosis-like symptoms in humans, is considered a valuable assay in preclinical research and is widely used to screen novel compounds for antipsychotic efficacy (Ratajczak et al., 2013; Steeds 
TABLE 2

In vitro functional profile of SEP-856.

The functional effects of SEP-856 were determined for receptors at which $>50 \%$ inhibition was seen in the panel screens. The in vitro pharmacology studies were run in both agonist and antagonist modes. The specific assays are listed in Materials and Methods. Data are shown as mean \pm S.E.M. $(n \geq 3)$.

\begin{tabular}{|c|c|c|c|c|}
\hline \multirow[t]{2}{*}{ Receptor } & \multicolumn{2}{|c|}{ Agonist } & \multicolumn{2}{|c|}{ Antagonist } \\
\hline & $\mathrm{EC}_{50}(\mu \mathrm{M})$ & $\% \mathrm{E}_{\max }$ & $\mathrm{IC}_{50}(\mu \mathrm{M})$ & $\%$ Inhibition \\
\hline TAAR1 & $0.140 \pm 0.062$ & $101.3 \pm 1.3$ & $\mathrm{NE}$ & $\mathrm{NE}$ \\
\hline $5-\mathrm{HT}_{1 \mathrm{~A}}$ & $2.3 \pm 1.40$ & $74.7 \pm 19.6$ & $\mathrm{NE}$ & $\mathrm{NE}$ \\
\hline $5-\mathrm{HT}_{1 \mathrm{~B}}$ & $15.6 \pm 11.60$ & $22.4 \pm 10.9$ & $\mathrm{NE}$ & $\mathrm{NE}$ \\
\hline $5-\mathrm{HT}_{1 \mathrm{D}}$ & $0.262 \pm 0.09$ & $57.1 \pm 6.0$ & $\mathrm{NE}$ & $\mathrm{NE}$ \\
\hline $5-\mathrm{HT}_{2 \mathrm{~A}}$ & $>10$ & $29.3 @ 10 \mu \mathrm{M}$ & $\mathrm{NE}$ & $\mathrm{NE}$ \\
\hline $5-\mathrm{HT}_{2 \mathrm{C}}$ & $30 \pm 4.5$ & $63.3 \pm 3.1$ & $\mathrm{NE}$ & $\mathrm{NE}$ \\
\hline $5-\mathrm{HT}_{7}$ & $6.7 \pm 1.32$ & $41.0 \pm 9.5$ & $\mathrm{NE}$ & $\mathrm{NE}$ \\
\hline$\alpha_{2 \mathrm{~A}}$ & $>10$ & $39.4 \pm 4.2$ & $\mathrm{NE}$ & $\mathrm{NE}$ \\
\hline$\alpha_{2 \mathrm{~B}}$ & $\mathrm{NE}$ & $\mathrm{NE}$ & $\mathrm{NE}$ & $\mathrm{NE}$ \\
\hline $\mathrm{D}_{2 \mathrm{~L}}(\mathrm{cAMP})$ & $10.44 \pm 4.0$ & $23.9 @ 10 \mu \mathrm{M}$ & $>100$ & $34.0 \pm 1.16$ \\
\hline $\mathrm{D}_{2 \mathrm{~L}}$ (arrestin recruitment) & 8.02 & $27.1 @ 10 \mu \mathrm{M}$ & $>100$ & $<25 @ 100 \mu \mathrm{M}$ \\
\hline
\end{tabular}

$\mathrm{NE}$, no effect $(<30 \% @ 30 \mu \mathrm{M})$.

et al., 2015; Moffat et al., 2017). Single oral administration of SEP-856 $(0.3,1$, and $3 \mathrm{mg} / \mathrm{kg}$; 30 -minute pretreatment time) resulted in a dose-dependent inhibition of PCPinduced hyperactivity responses in $\mathrm{C} 57 \mathrm{BL} / 6 \mathrm{~J}$ mice (oneway $\operatorname{ANOVA~F}_{(5,59)}=18.96, P<0.0001$; Tukey's post hoc test, $P<0.05$ ) with an $\mathrm{ED}_{50}$ of approximately $0.3 \mathrm{mg} / \mathrm{kg}$ (Fig. 3A). The positive control, clozapine, also significantly reduced PCP-induced hyperactivity. Small but significant decreases in baseline activity were observed with SEP-856 at the highest dose of $3 \mathrm{mg} / \mathrm{kg}$ (one-way
$\operatorname{ANOVA~F}_{(5,59)}=5.5, P<0.001$; Tukey's post hoc test, $P<$ 0.05; Supplemental Fig. 3A).

Another behavioral assay that is routinely used to identify novel antipsychotic agents is PPI of the acoustic startle response (Geyer et al., 2001). PPI occurs when a startle-eliciting stimulus (i.e., the pulse) is preceded by a stimulus of lower intensity (i.e., the prepulse) and the amplitude of the startle response is reduced. Single oral administration of SEP-856 (0.3, 1, 3, 10, and $30 \mathrm{mg} / \mathrm{kg} ; 30$ minute pretreatment time) in $\mathrm{C} 57 \mathrm{BL} / 6 \mathrm{~J}$ mice resulted in

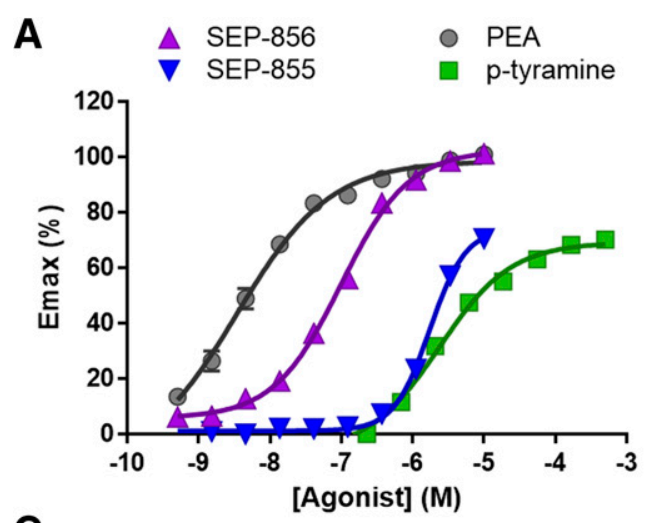

B

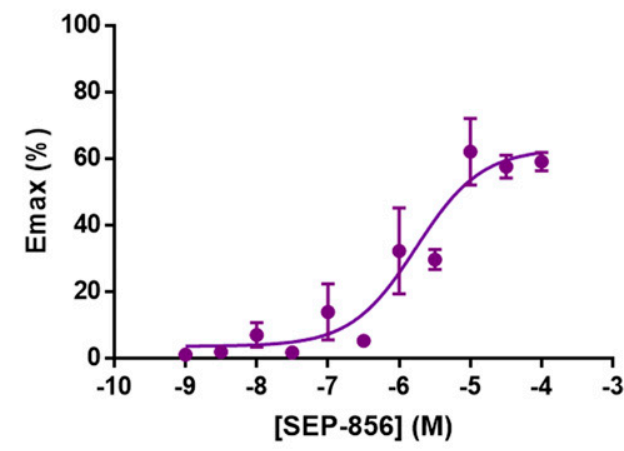

C

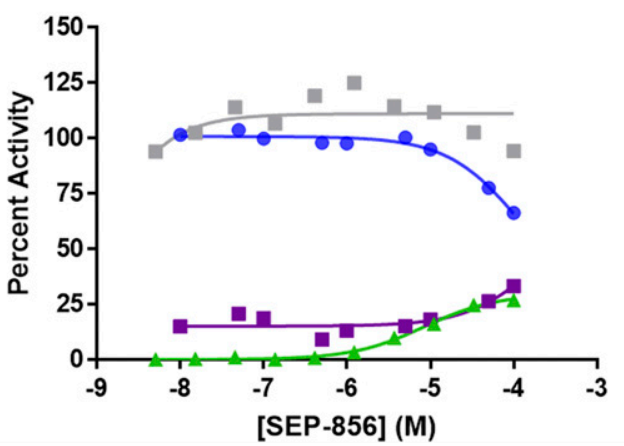

\footnotetext{
$\pm \beta$-arrestin agonism

-- $\beta$-arrestin antagonism

$\rightarrow$ - cAMP agonism

- cAMP antagonism
}

[SEP-856] (M)

Fig. 2. Functional effects of SEP-856 at TAAR1, 5-HT $1 \mathrm{~A}$, and $\mathrm{D}_{2}$ receptors. The functional effects of SEP-856 were determined using HEK-293 cells expressing TAAR1 (A), 5-HT $1 \mathrm{~A}(\mathrm{~B})$, or $\mathrm{D}_{2}$ (C) receptors. cAMP accumulation was determined for TAAR1 using the DiscoveRx HitHunter cAMP assay. The inactive enantiomer of SEP-856 (SEP-855) was also tested along with the trace amines phenethylamine (PEA) and p-tyramine. Inhibition of forskolinstimulated cAMP levels was used for the $5-\mathrm{HT}_{1 \mathrm{~A}}(n=4)$ and $\mathrm{D}_{2}$ receptors; cAMP levels were determined with the DiscoveRx HitHunter cAMP XS ${ }^{+}$ assay or the Cisbio HTRF, cAMP assay. The $\mathrm{D}_{2}$ receptor was also studied using the PathHunter $\beta$-arrestin recruitment assay. Representative traces are shown for (A and C). 

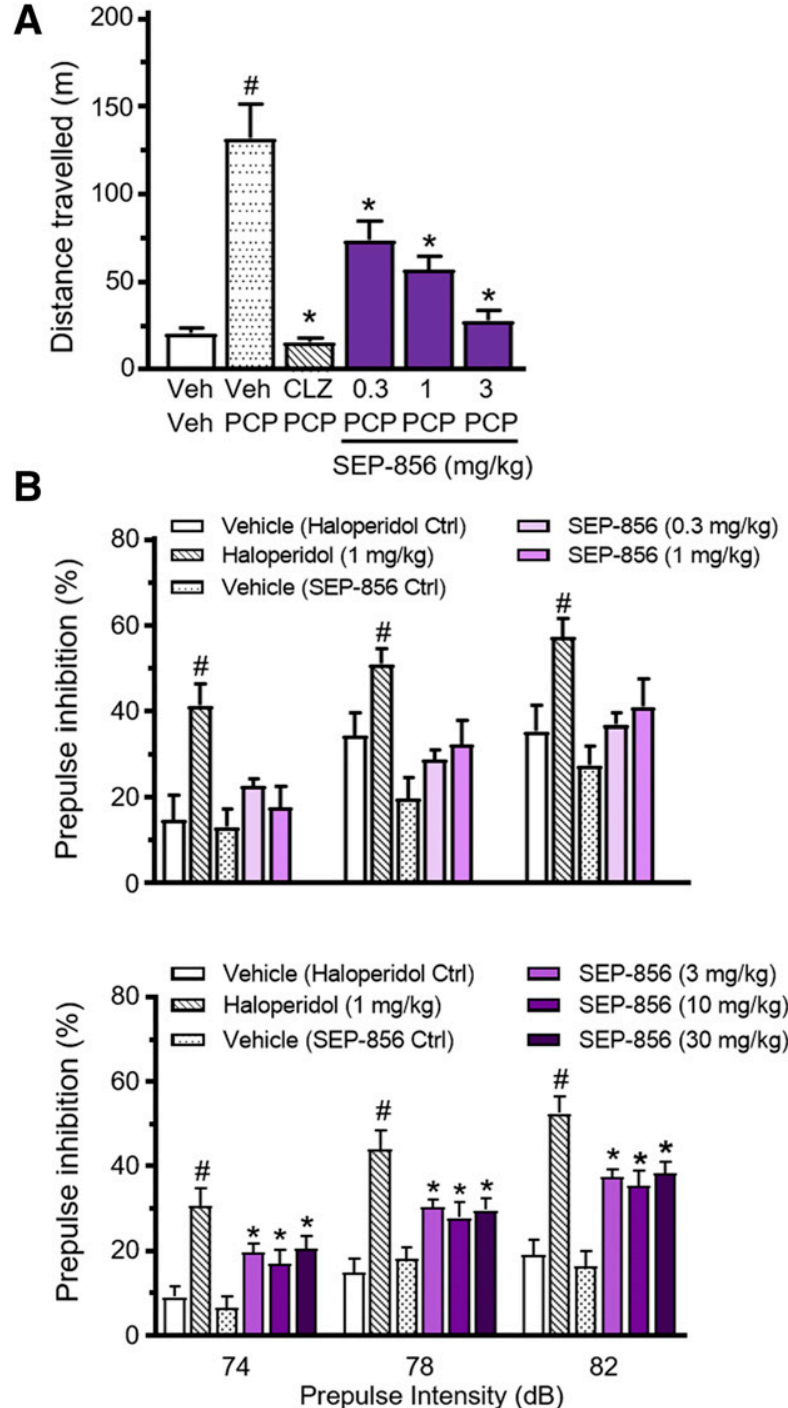
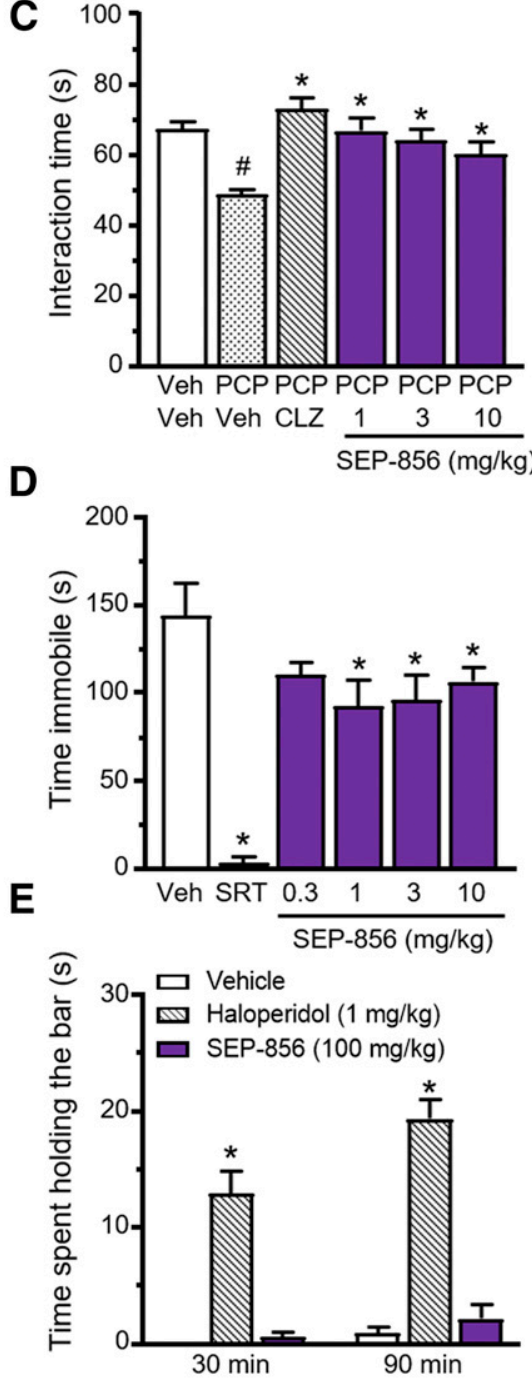

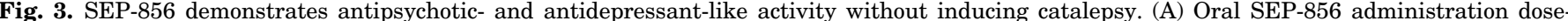

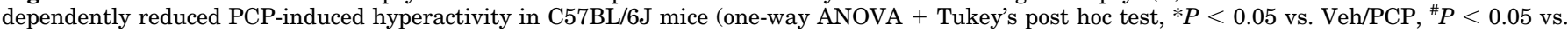

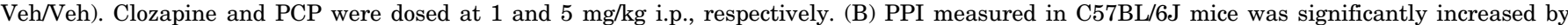

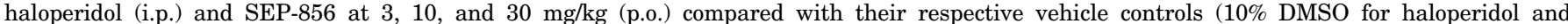

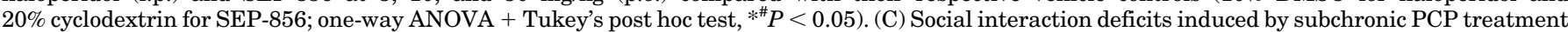

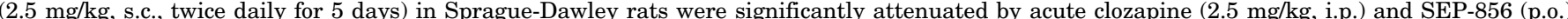

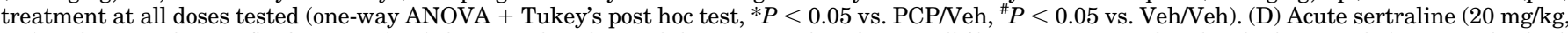

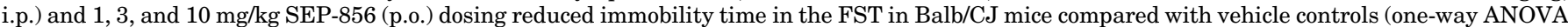

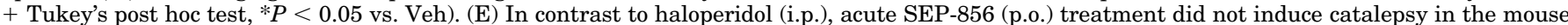

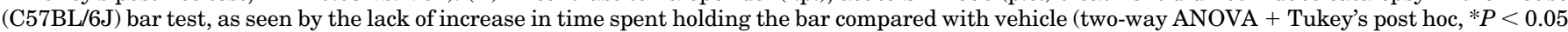
vs. Veh). CLZ, clozapine; SRT, sertraline. $N=8-12$ /group. Data are shown as mean \pm S.E.M.

a dose-dependent increase in PPI compared with the respective vehicle treatment (Fig. 3B), with significant increases observed at 3,10 , and $30 \mathrm{mg} / \mathrm{kg}$ (two-way ANOVA: treatment effect $\mathrm{F}_{(3,102)}=19.9, P<0.0001$; db effect $\mathrm{F}_{(2,102)}$ $=30.97, P<0.0001$; Dunnett's post hoc test, $P<0.05)$. Unlike the positive control haloperidol, SEP-856 improved PPI at dose levels that had no confounding effects on baseline startle responses (Supplemental Fig. 3B).

In contrast to positive symptoms, negative symptoms of schizophrenia, including anhedonia, blunted affect, and social withdrawal, are more difficult to model in animals (Jones et al., 2011; Wilson et al., 2015). However, subchronic treatment with PCP reliably produces social interaction deficits in rodents that may mimic certain aspects of negative symptoms such as social withdrawal (Steeds et al., 2015). Sprague-Dawley rats were subcutaneously injected with PCP $(2 \mathrm{mg} / \mathrm{kg}$ ) or vehicle twice daily for 5 consecutive days, followed by behavioral assessment on day 6 . The PCP-induced deficit in social interaction was significantly attenuated by single oral administration of SEP-856 at 1,3 , and $10 \mathrm{mg} / \mathrm{kg}$ (one-way ANOVA $_{(5,56)}=8.33, P<0.0001$; Tukey's post hoc test, $P<0.05)$. The positive control, clozapine $(2.5 \mathrm{mg} / \mathrm{kg}$, i.p. $)$, also showed efficacy that was comparable to SEP-856 (Fig. 3C). This suggests that SEP-856 may have potential benefits against some of the negative symptoms of schizophrenia, such as social withdrawal.

The effects of SEP-856 $(0.3,1,3$, and $10 \mathrm{mg} / \mathrm{kg})$ were additionally evaluated in the mouse FST, a behavioral assay 
that is acutely sensitive to all major classes of marketed antidepressants drugs (Porsolt et al., 1977). Single oral administration of SEP-856 significantly reduced immobility time at 1,3 , and $10 \mathrm{mg} / \mathrm{kg}$ compared with vehicle (one-way $\operatorname{ANOVA~}_{(5,44)}=13.24, P<0.0001$; Tukey's post hoc test, $P<0.05$; Fig. 3D), suggesting that SEP-856 may also exhibit antidepressant-like activity. However, no clear dosedependent effect was observed, and the magnitude of response was smaller than that produced by the positive control sertraline $(20 \mathrm{mg} / \mathrm{kg}$, i.p.).

One of the issues associated with antipsychotic drugs is the potential to develop extrapyramidal symptoms (EPS), which can be assessed in mice by measuring the induction of catalepsy using the bar test. Oral administration of SEP-856 (100 $\mathrm{mg} / \mathrm{kg}$ ) produced no effects in the bar test, whereas haloperidol ( $1 \mathrm{mg} / \mathrm{kg}$, i.p.) significantly increased the amount of time mice spent holding the bar at 30 - and 90-minute postdosing (two-way ANOVA: treatment effect $\mathrm{F}_{(2,54)}=107.7$, $P<0.0001$; time effect $\mathrm{F}_{(1,54)}=9.4, P<0.005$; Dunnet's post hoc test, $P<0.05$ ). Importantly, these data indicate that SEP-856 was not associated with cataleptic effects at doses at least 30-fold higher than efficacious dose levels in mice (Fig. 3E).

The plasma and brain exposures to SEP-856 in the mouse PCP-induced hyperactivity and PPI tests as well as the rat subchronic PCP-induced social interaction test are shown in Supplemental Table 6. Taken together, our results indicate a clear antipsychotic-like profile of SEP-856 in rodents and corroborate the initial findings obtained in the behavioral screening platform.

SEP-856 Decreases Rapid Eye Movement Sleep. The activation of $5-\mathrm{HT}_{1 \mathrm{~A}}$ and TAAR1 has been shown to promote a generalized increase in wakefulness, increased latency to sleep, and suppression of rapid eye movement (REM) sleep (Revel et al., 2012b; Black et al., 2017; Schwartz et al., 2017). Because SEP-856 exhibits agonism at and TAAR1 and 5$\mathrm{HT}_{1 \mathrm{~A}}$, we investigated whether it affects sleep architecture, as determined by telemetric recordings of the EEG, electromyogram, $\mathrm{Tb}$, and locomotor activity in Sprague-Dawley rats. SEP-856 and the positive control caffeine were administered during the middle of the light (inactive) period, followed by
6 hours of recordings. Oral SEP-856 administration (1, 3, and $10 \mathrm{mg} / \mathrm{kg}$ ) produced a dose-dependent decrease in REM sleep, increase in latency to REM sleep, and increase in cumulative wake time (Fig. 4, A and B; Supplemental Fig. 4). SEP-856 had no effect on the cumulative non-REM time and latency to nonREM (Supplemental Fig. 4). The differential effect on REM was further evident by a dose-dependent decrease in the REM: non-REM ratio (Fig. 4C). Caffeine promoted wakefulness, as expected, with additional characteristic increases in locomotion and Tb that SEP-856 did not produce (Supplemental Fig. 4). Collectively, these results suggest that SEP-856 promotes vigilance when given during the light (inactive) phase.

SEP-856 Interacts with Central 5-HT 1 but Not $D_{2}$ Receptors. In addition to TAAR1, in vitro testing revealed that SEP-856 exhibits agonist activity at $5-\mathrm{HT}_{1 \mathrm{~A}}$ and $\mathrm{D}_{2}$ receptors . Consequently, we conducted a series of experiments to determine whether SEP-856 interacts with these two targets in vivo.

First, receptor autoradiography was used to assess SEP-856 occupancy at $\mathrm{D}_{2}$ receptors in the rat brain using the radioligand $\left[{ }^{3} \mathrm{H}\right]$-raclopride. SEP-856 $(10 \mathrm{mg} / \mathrm{kg}$, i.p.) or vehicle was administered to Sprague-Dawley rats, followed by administration of $\left[{ }^{3} \mathrm{H}\right]$-raclopride $(60 \mu \mathrm{Ci} / \mathrm{kg}$, i.v. $) 30$ minutes later. $\mathrm{D}_{2}$ receptor occupancy was assessed at 60 minutes post-SEP-856 (or vehicle) administration in coronal sections of the striatum (region of interest) and cerebellum (reference region). Despite high plasma ( 1300 ng/ml), brain ( 7900 ng/g), and CSF $(\sim 1800 \mathrm{ng} / \mathrm{ml})$ exposures, SEP-856 resulted in $12.6 \% \pm$ $6.4 \%$ receptor occupancy at $\mathrm{D}_{2}$ (Supplemental Table 7 ), which was not statistically different from vehicle controls (two-tailed $t$ test, $P=0.27$ ). For comparison, activity in the rat PCPinduced social interaction deficit assay $(1-10 \mathrm{mg} / \mathrm{kg}$ ) and mouse PCP-induced hyperactivity test $(0.3-3 \mathrm{mg} / \mathrm{kg})$ was seen at much lower exposures (Supplemental Table 6). Thus, acute administration of SEP-856 did not produce significant occupancy at $D_{2}$ receptors in the rat brain at plasma concentrations up to 200 -fold greater than those that were behaviorally efficacious.

We additionally conducted in vivo positron emission tomography imaging to determine whether SEP-856 also fails to occupy $\mathrm{D}_{2}$ receptors in the nonhuman primate brain. Imaging
A

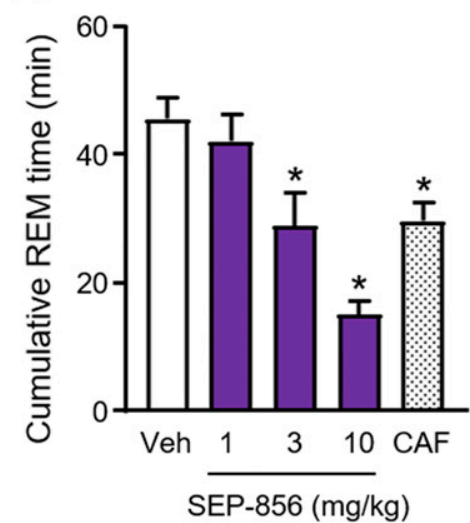

B

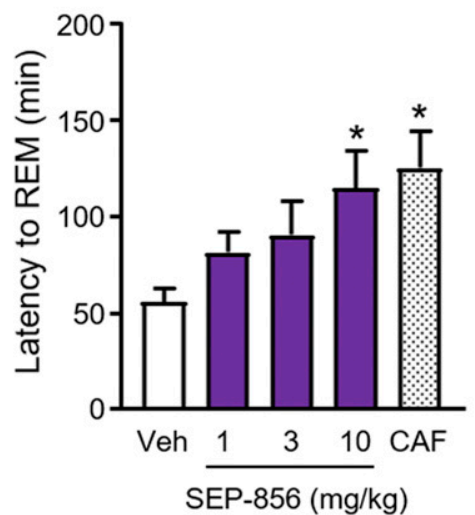

C

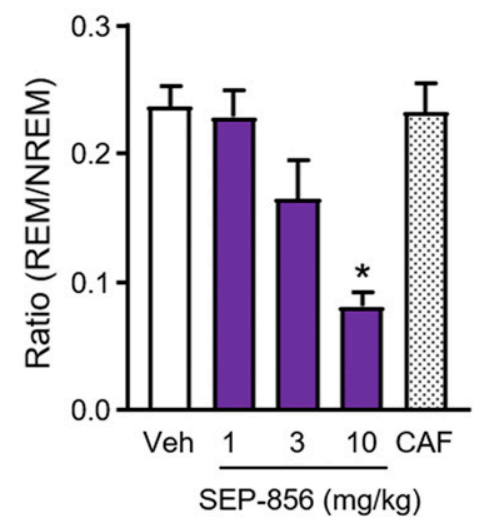

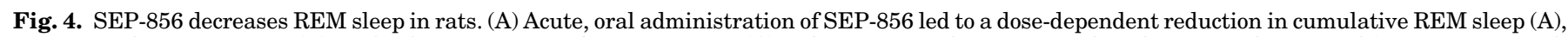

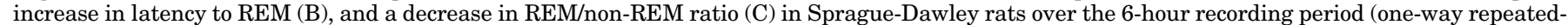

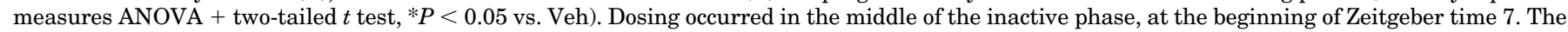

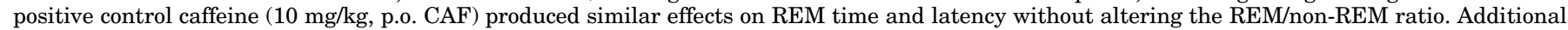
parameters are presented in Supplemental Fig. $4 . N=7$. Data are shown as mean \pm S.E.M. 
was conducted in two anesthetized baboons using the radiotracer $\left[{ }^{18} \mathrm{~F}\right]$-fallypride. The percent occupancy was evaluated using a blockade protocol comparing $\left[{ }^{18} \mathrm{~F}\right]$-fallypride regional binding potential at baseline and following SEP-856 administration $\left(\sim 7.25 \mathrm{mg} / \mathrm{kg}\right.$, i.v. 30 minutes prior to $\left[{ }^{18} \mathrm{~F}\right]$-fallypride injection). Venous blood samples were taken before and at various time points after SEP-856 administration. SEP-856 showed $\mathrm{D}_{2}$ receptor occupancy levels of $9.1 \% \pm 3.3 \%, 6.2 \% \pm$ $6.1 \%$, and $9.6 \% \pm 8.8 \%$ in the caudate, putamen, and globus pallidus, respectively (Fig. 5; Supplemental Table 8). Similar to the observations in rats, SEP-856 did not produce significant occupancy at $D_{2}$ receptors despite achieving high plasma concentrations (i.e., $2850 \pm 250 \mathrm{ng} / \mathrm{ml}$ at 60 minutes and $1765 \pm 125 \mathrm{ng} / \mathrm{ml}$ at 180 minutes after SEP-856 administration). Importantly, this finding demonstrates that the antipsychotic-like behavioral profile of SEP-856 is independent of direct $\mathrm{D}_{2}$ receptor modulation.

Next, we used in vitro autoradiography to evaluate the effects of SEP-856 on $\left[{ }^{3} \mathrm{H}\right]-8-\mathrm{OH}-\mathrm{DPAT}$ (a $5-\mathrm{HT}_{1 \mathrm{~A}}$ agonist radioligand) binding to $5-\mathrm{HT}_{1 \mathrm{~A}}$ receptors in the rat brain. Slide-mounted rat brain sections were incubated with $2 \mathrm{nM}$ $\left[{ }^{3} \mathrm{H}\right]-8-\mathrm{OH}-\mathrm{DPAT}$ in the presence and absence of SEP-856 (0.1, 1 , and $10 \mu \mathrm{M})$. Nonspecific binding was defined by $10 \mu \mathrm{M} 5$ HT. SEP-856 produced a concentration-dependent displacement of $\left[{ }^{3} \mathrm{H}\right]-8-\mathrm{OH}-\mathrm{DPAT}$ binding in all regions evaluated (Supplemental Fig. 5). Given the similar degree of $\left[{ }^{3} \mathrm{H}\right]-8-\mathrm{OH}-$ DPAT binding in all brain areas, $\mathrm{IC}_{50}$ values for SEP-856 displacement of $\left[{ }^{3} \mathrm{H}\right]-8-\mathrm{OH}-D P A T$ binding were only determined for the septum and motor/somatosensory cortex (referred to as cortex). SEP-856 displaced $\left[{ }^{3} \mathrm{H}\right]-8-\mathrm{OH}-\mathrm{DPAT}$ in a concentration-dependent manner, with a mean $\mathrm{IC}_{50}$ of 619 and $791 \mathrm{nM}$ in the cortex and septum, respectively (Fig. 6). These results demonstrate that SEP-856 can bind to central $5-\mathrm{HT}_{1 \mathrm{~A}}$ receptor sites in vitro.

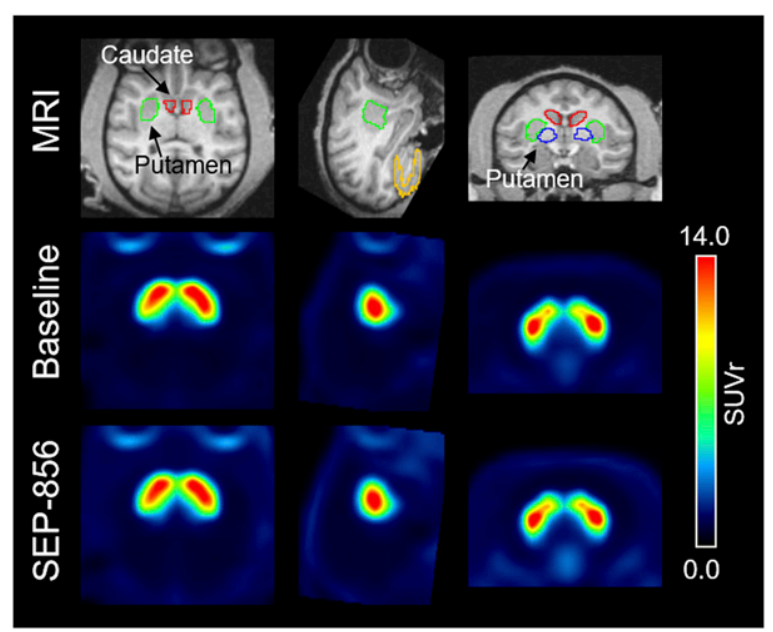

Fig. 5. SEP-856 does not exhibit significant occupancy at $D_{2}$ receptors in nonhuman primates. Representative magnetic resonance (for anatomic reference) and mean summed positron emission tomography images, before and after administration of SEP-856, are shown from top to bottom for one animal. Axial, sagittal, and coronal slices are shown from left to right. Regions of interest, including the caudate, putamen, and globus pallidus, were manually outlined. Average $\left[{ }^{18} \mathrm{~F}\right]$ fallypride positron emission tomography images over 180 minutes of acquisition are presented at baseline and following bolus i.v. administration of SEP-856 (7.25 mg/kg). The occupancy was estimated using the $B P_{N D}$-derived Simplified Reference Tissue Model. SUVr, relative standardized uptake value.
SEP-856 Inhibits Neuronal Firing in the DRN and VTA In Vitro. To investigate the effect of SEP-856 on neuronal activity and obtain further insights into its mechanism of action, we performed whole-cell patch-clamp recordings in isolated slice preparations of the DRN and the VTA of C57BL/6J mice. The DRN and VTA express a high abundance of $5-\mathrm{HT}_{1 \mathrm{~A}}$ and TAAR1 receptors, respectively (Lindemann et al., 2008; Celada et al., 2013; Christian and Berry, 2018). After the determination of repeatable responses, administration of SEP-856 was repeated in the presence of the selective TAAR1 antagonist EPPTB and/or the selective $5-\mathrm{HT}_{1 \mathrm{~A}}$ receptor antagonist WAY-100635.

Whole-cell current-clamp recordings were made from 29 neurons within the $\mathrm{DRN}$ with a mean resting membrane potential of $-46.1 \pm 1.0 \mathrm{mV}$ and a mean input resistance of $849 \pm 61 \mathrm{M} \Omega$. Based on changes in membrane potential and firing rates, 16 of the DRN neurons were characterized as being sensitive to the $5-\mathrm{HT}_{1 \mathrm{~A}}$ agonist 8-OH-DPAT (DPAT), and 13 were classified as DPAT-insensitive (Supplemental Fig. 6). Based on their initial threshold activity, $44 \%$ (7 of 16) of DPAT-sensitive neurons were characterized as spontaneously active (discharging action potentials) and $56 \%$ (9 of 16) were quiescent. SEP-856 (10 $\mu \mathrm{M})$ induced significant membrane hyperpolarization in eight of nine quiescent neurons $(45.5 \pm$ 1.9 to $-49.0 \pm 2.2 \mathrm{mV}$, post-SEP-856 washout to $46.1 \pm 1.9$ $\mathrm{mV}$; paired two-tailed $t$ test, $\mathrm{t}_{7}=4.3, P=0.004$; Fig. 7A). In contrast, one single neuron was depolarized by $2.1 \mathrm{mV}$. SEP856 also significantly reduced the activity of five of seven spontaneously active DRN neurons $(0.31 \pm 0.10 \mathrm{~Hz}$ to $0.11 \pm$ 0.04 , post-SEP-856 washout to $0.20 \pm 0.06 \mathrm{~Hz} ; 69 \% \pm$ $9.7 \%$ reduction; paired two-tailed $t$ test, $\mathrm{t}_{4}=3.2, P=0.03$; Fig. 7A), whereas the remaining two neurons were largely unaffected. Collectively, administration of $10 \mu \mathrm{M}$ SEP-856 induced an inhibitory response, determined by either a membrane hyperpolarization or a reduction in spontaneous firing rate, in $81 \%$ (13 of 16) of DPAT-sensitive neurons. In contrast, SEP-856 only induced an inhibitory response in $15 \%$ (2 of 13 ) of DPAT-insensitive neurons (Supplemental Fig. 6).

Next, the effects of $10 \mu \mathrm{M}$ SEP-856 were examined in the presence of the $5-\mathrm{HT}_{1 \mathrm{~A}}$ antagonist WAY-100635 $(1 \mu \mathrm{M})$ in five DPAT-sensitive DRN neurons, two of which were spontaneously active and three of which were quiescent. In three of the five neurons, a membrane hyperpolarization of $1.9 \pm 0.4 \mathrm{mV}$ induced by SEP-856 was markedly reduced to $0.4 \pm 0.1 \mathrm{mV}$ when SEP-856 was reapplied in the presence of WAY-100635 (79\% reduction; Fig. 7B; Supplemental Fig. 6). Similarly, the inhibitory effect of SEP-856 was almost completely blocked in a further neuron in the presence of WAY-100635, with the spontaneous firing rate being reduced by $47 \%(0.21-0.11 \mathrm{~Hz})$ during control SEP-856 administration compared with just a $2 \%$ reduction $(0.83-0.82 \mathrm{~Hz})$ when $\mathrm{SEP}-856$ was applied in the presence of WAY-100635 (Fig. 7B). In the remaining neuron, a $2.4 \mathrm{mV}$ hyperpolarization induced by SEP-856 was slightly increased to $2.6 \mathrm{mV}$ in the presence of WAY-100635. Thus, the inhibitory response induced by SEP-856 was reduced in the presence of the 5- $\mathrm{HT}_{1 \mathrm{~A}}$ antagonist WAY-100635, in the majority ( 4 of $5,80 \%$ ) of DRN neurons analyzed.

In addition, the effects of SEP-856 were examined in the presence of EPPTB in six DPAT-sensitive DRN neurons, three of which were spontaneously firing action potentials and three of which were quiescent. Overall, the inhibitory response induced by SEP-856 was unaffected in the presence of the 
A

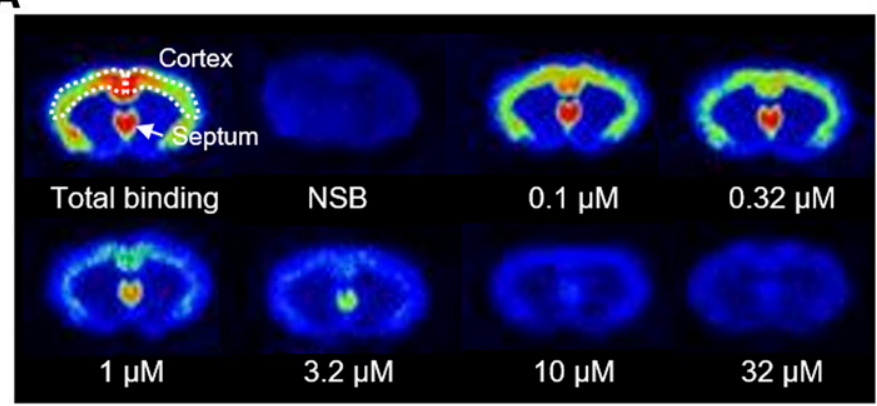

B

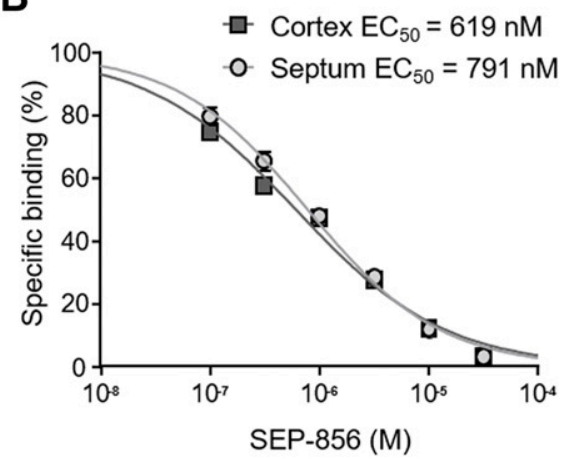

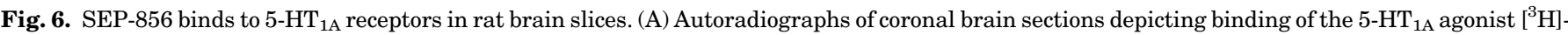

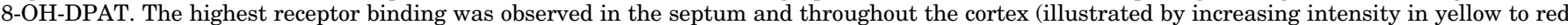

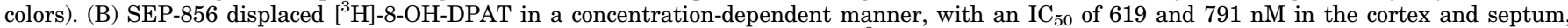

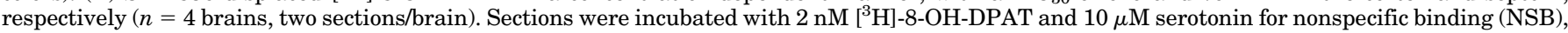
0.1\% DMSO for total binding, or SEP-856 (0.1-32 $\mu \mathrm{M})$. Data are shown as mean \pm S.E.M.

TAAR1 antagonist EPPTB, in the majority (5 of $6,83 \%$ ) of DRN neurons tested (Fig. 7C).

Following the assessment of SEP-856 effects on DRN neuronal firing, whole-cell patch-clamp recordings were also made from 23 neurons within the VTA (mean resting membrane potential of $-40.7 \pm 0.7 \mathrm{mV}$ and a mean input resistance of $935 \pm 104 \mathrm{M} \Omega$ ) (Supplemental Fig. 7). All of these neurons were spontaneously active once whole-cell configuration had been established with a mean firing rate of $1.97 \pm 0.60 \mathrm{~Hz}$, although activity did not persist in all cases. SEP-856 induced an inhibitory response in approximately half of the recorded VTA neurons (Fig. 7D; Supplemental Fig. 7). This response was characterized by a significant hyperpolarization of $2.8 \pm 0.5 \mathrm{mV}$ in $42 \%$ (8 of 19) of the neurons $(-42.6 \pm$ 1.3 to $-45.3 \pm 1.4 \mathrm{mV}$; paired two-tailed $t$ test, $\mathrm{t}_{7}=5.8, P=$ $0.0007)$ and a significant reduction in spontaneous firing rate in $55 \%$ ( 11 of 20 ) of the neurons (from $0.6 \pm 0.18$ to $0.18 \pm 0.07$ $\mathrm{Hz} ; 71.4 \% \pm 7 \%$ reduction; paired two-tailed $t$ test, $\mathrm{t}_{10}=3.3$, $P<0.008$; Fig. 7D).

Interestingly, recordings from two neurons showed that the inhibitory response of SEP-856 $(1 \mu \mathrm{M})$ was reduced in the presence of $1 \mu \mathrm{M}$ EPPTB (Fig. 7F), but persisted in the presence of the 5-HT $1 \mathrm{~A}$ antagonist WAY-100635 (Fig. 7E). However, observations from additional neurons are necessary to further validate the ability of EPPTB to attenuate the inhibitory effect of SEP-856 in the VTA.

Overall, SEP-856 induced significant inhibitory responses in DPAT-sensitive neurons of the DRN and a subset of VTA neurons. In contrast to the inhibitory effects of SEP-856 in the DRN, which were primarily mediated via activation of $5-\mathrm{HT}_{1 \mathrm{~A}}$ receptors, the response in the VTA appeared to be at least partially mediated via the activation of TAAR1.

SEP-856 Inhibits DRN Neuronal Firing In Vivo. The observation that SEP-856's inhibitory effects in the DRN were mediated by $5-\mathrm{HT}_{1 \mathrm{~A}}$ led us to additionally investigate DRN neuronal firing in vivo by recording extracellular single-unit activities in anesthetized Sprague-Dawley rats. In accordance with previous work (Martin et al., 1999), application of 8-OHDPAT inhibited DRN firing, which was subsequently reversed by $0.08 \mathrm{mg} / \mathrm{kg}$ WAY-100635 (Supplemental Fig. 8). SEP-856 ( $2 \mathrm{mg} / \mathrm{kg}$, i.v.) significantly decreased DRN neuron discharges to $87 \%$ of the baseline rate (from $9.83 \pm 1.4$ to $1.4 \pm 0.33$ spikes/10 seconds; two-tailed $t$ test, $\left.\mathrm{t}_{2}=5.9, P<0.03\right)$ during the initial 10 minutes postdosing (Fig. 8, A and B). Thirty minutes after SEP-856 administration, the inhibitory effect was no longer detectable and firing rates were restored to baseline levels. SEP-856 plasma exposures determined 30 minutes postdosing were $422 \pm 22.5 \mathrm{ng} / \mathrm{ml}$. When SEP856 was tested at a higher dose $(5 \mathrm{mg} / \mathrm{kg}$, i.v.), firing activity was completely suppressed and the inhibition was fully reversed by intravenous administration of $0.08 \mathrm{mg} / \mathrm{kg}$ WAY-100635 (Fig. 8, C and D). Similarly, the inhibitory effect of $2 \mathrm{mg} / \mathrm{kg}$ SEP-856 was also reversed by WAY-100635 (Supplemental Fig. 8). These results support the earlier in vitro finding in mice, and further suggest that part of SEP-856's mechanism of action is characterized by suppression of serotonergic neuronal firing via activation of $5-\mathrm{HT}_{1 \mathrm{~A}}$ autoreceptors.

SEP-856 Does Not Alter Dopamine and Serotonin Release in the Striatum or Prefrontal Cortex. To determine whether the inhibitory action of SEP-856 in DRN neurons translates into changes in synaptic serotonin levels, we measured 5-HT release in vivo using microdialysis in freely-moving rats. Although SEP-856 demonstrated no occupancy at $\mathrm{D}_{2}$ receptors in vivo, its antipsychotic-like behavioral profile, TAAR1 activity, and ability to inhibit VTA neurons suggest potential modulation of dopaminergic circuits independent of direct dopamine receptor regulation. We therefore also assessed dopamine release. Changes in monoamine levels were monitored over a 240-minute period following oral administration of vehicle, 3,10 , or $30 \mathrm{mg} / \mathrm{kg}$ SEP-856. Interestingly, no significant changes in extracellular levels of dopamine or 5-HT were observed in striatum or prefrontal cortex following SEP-856 administration (Supplemental Fig. 9).

Antipsychotic-Like Effects of SEP-856 Are Partially

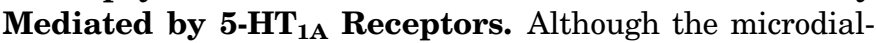
ysis findings revealed no changes in SEP-856-mediated 5-HT release, the in vitro pharmacology results as well as the slice and in vivo electrophysiology data suggest that agonism at $5-\mathrm{HT}_{1 \mathrm{~A}}$ receptors is integral to $\mathrm{SEP}-856$ 's mechanism of action in both mice and rats. Consequently, we evaluated whether the $5-\mathrm{HT}_{1 \mathrm{~A}}$ receptor antagonist WAY-100635 would attenuate the inhibitory behavioral effects of SEP-856 in the mouse PCPinduced hyperactivity test. C57BL/6J mice were injected with 
A

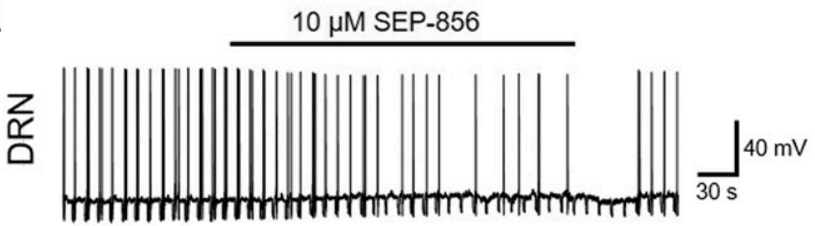

B

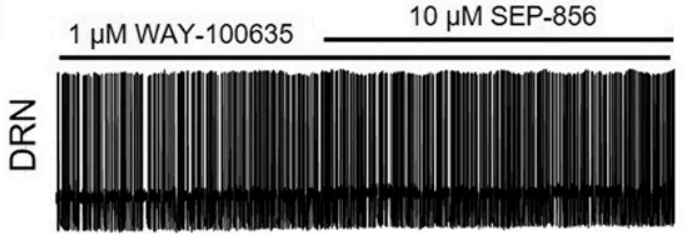
$\frac{\mathrm{J}}{30 \mathrm{~s}} 25 \mathrm{mV}$

C
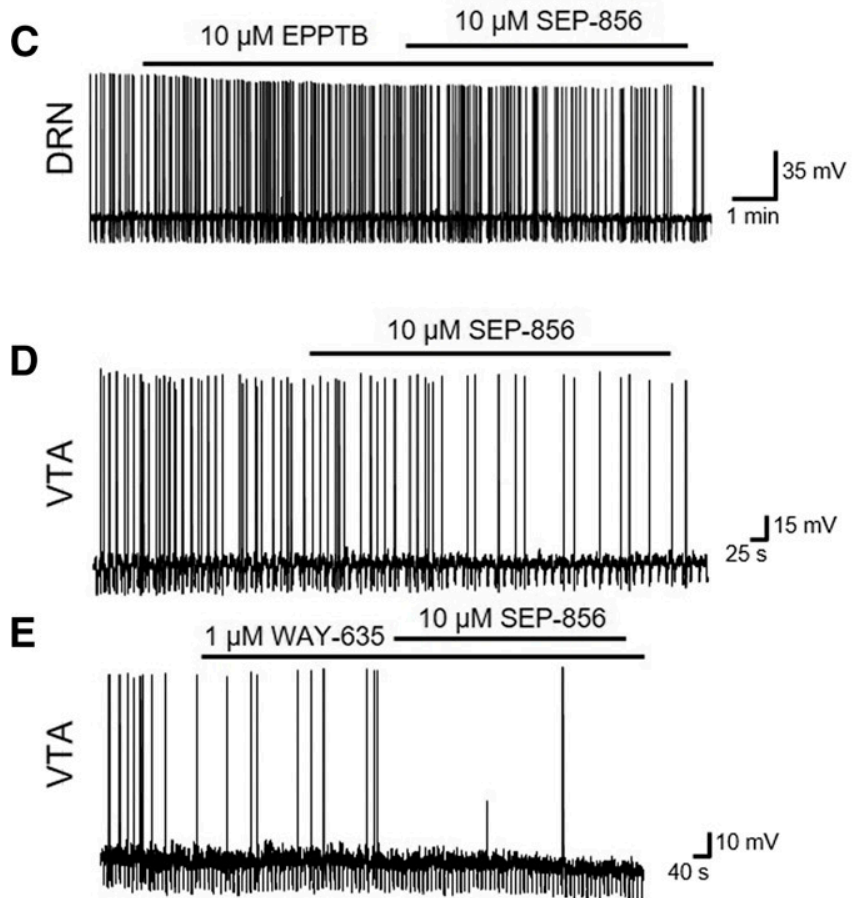

$\mathbf{F}$

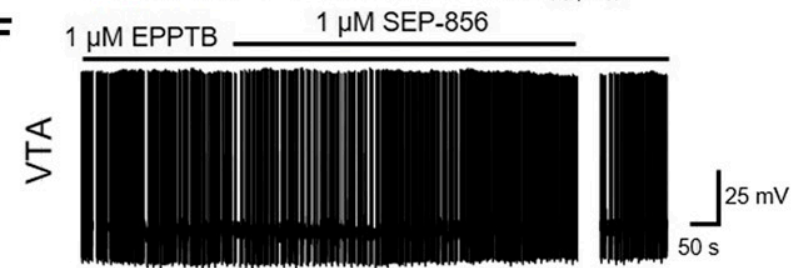

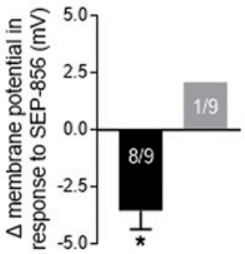
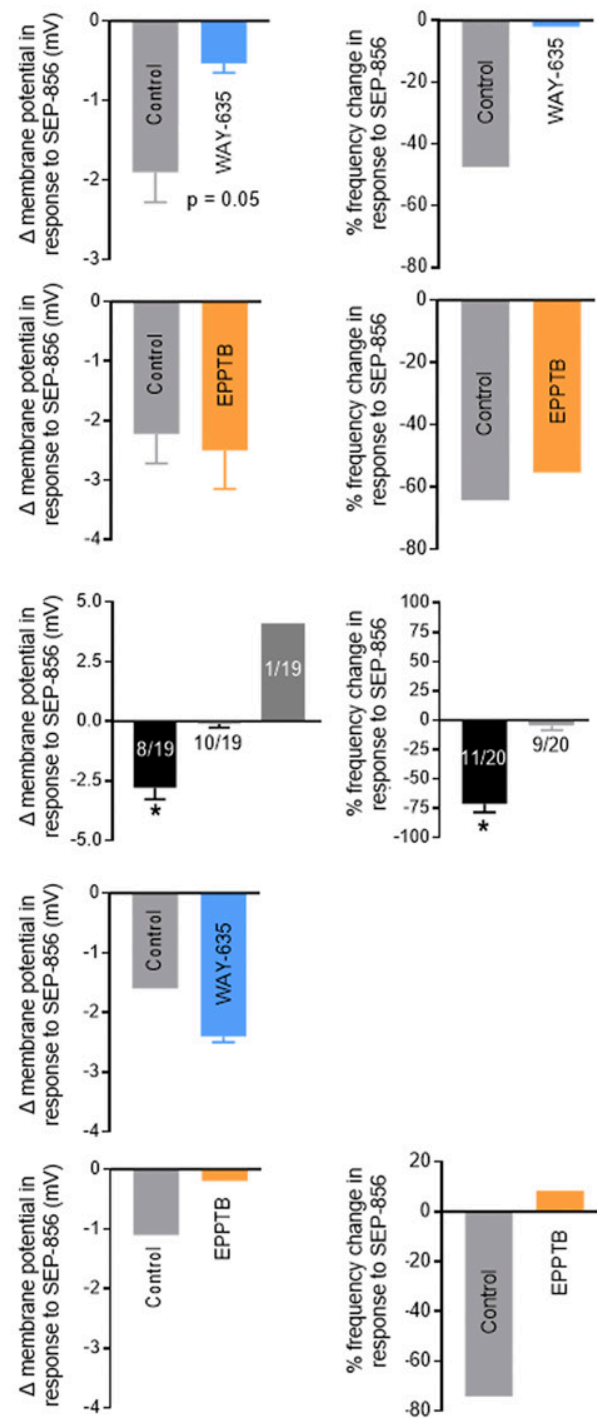

Fig. 7. SEP-856 inhibits firing of DRN and VTA neurons in vitro. Representative whole-cell patch-clamp recordings from DRN and VTA brain slices of C57BL/6J mice are shown on the left, and quantification histograms on the right. Compound-induced effects were determined based on significant changes in membrane potential (millivolts) and/or firing rate (Hertz) and expressed relative to baseline ( $\Delta$ membrane potential and \% frequency change). DRN neurons were classified as sensitive or insensitive to the 5-HT $1 \mathrm{~A}$ agonist 8-OH-DAPT. (A) SEP-856 induced inhibitory responses in the majority of spontaneously active, 8-OH-DAPT-sensitive DRN neurons. This inhibitory effect was absent in four of five neurons in the presence of the 5-HT 1 A antagonist WAY-100635 (B) but persisted in five of six neurons in the presence of the TAAR1 antagonist EPPTB (C). (D) Based on significant changes in membrane potential and/or firing rate, approximately half of the spontaneously-active neurons in the VTA were inhibited by SEP-856 treatment when compared with baseline. This effect persisted in presence of WAY-100635 ( $\mathrm{E}, n=2$ neurons) but was reduced in the presence of EPPTB (F, $n=2$ neurons). Histograms show neuronal responses following administration of SEP-856 alone (control, A and D) and in the presence of WAY-100635 (B and E) or EPPTB (C and F). Solid horizontal bars indicate the time frame of compound administration to the slice. Two-tailed $t$ test, ${ }^{*} P<0.05$. Abbreviations: WAY-100635 (WAY or WAY-635). Data are shown as mean \pm S.E.M.

WAY-100635 (1 mg/kg, i.p.) or saline (i.p.) 10 minutes prior to SEP-856 dosing (3 mg/kg, oral), followed by PCP administration $(5 \mathrm{mg} / \mathrm{kg}$, i.p.) 30 minutes later. Consistent with our previous findings, single oral administration of SEP-856 significantly inhibited PCP-induced hyperactivity responses (Fig. 8E). Pretreatment with WAY-100635 partially attenuated the inhibitory effects of SEP-856 on the total distance traveled (one-way ANOVA $\mathrm{F}_{(5,51)}=22.11, P<0.0001$; Tukey's post hoc test, $P<0.05$ ). Taken together, the results indicate that the antipsychotic-like effects of SEP-856 in the PCP-induced hyperactivity test may be partially mediated through $5-\mathrm{HT}_{1 \mathrm{~A}}$ receptors. 
A

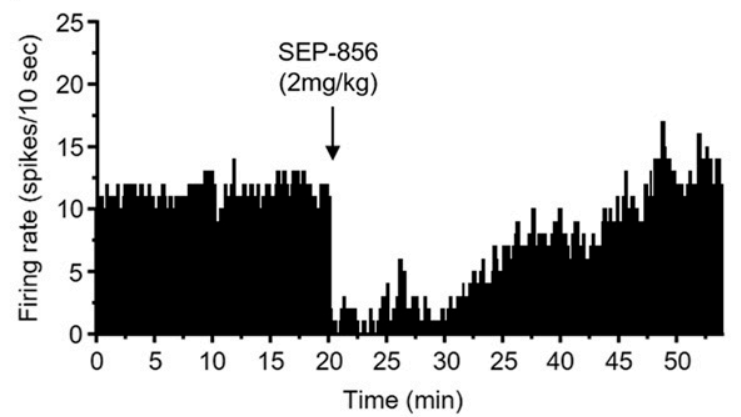

B

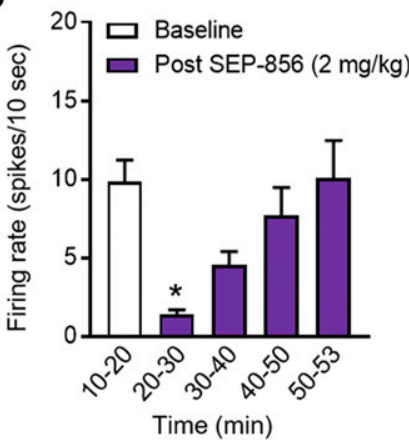

C

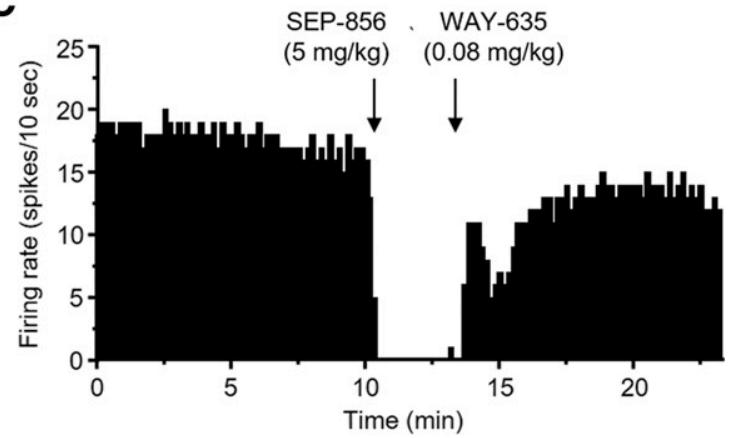

E
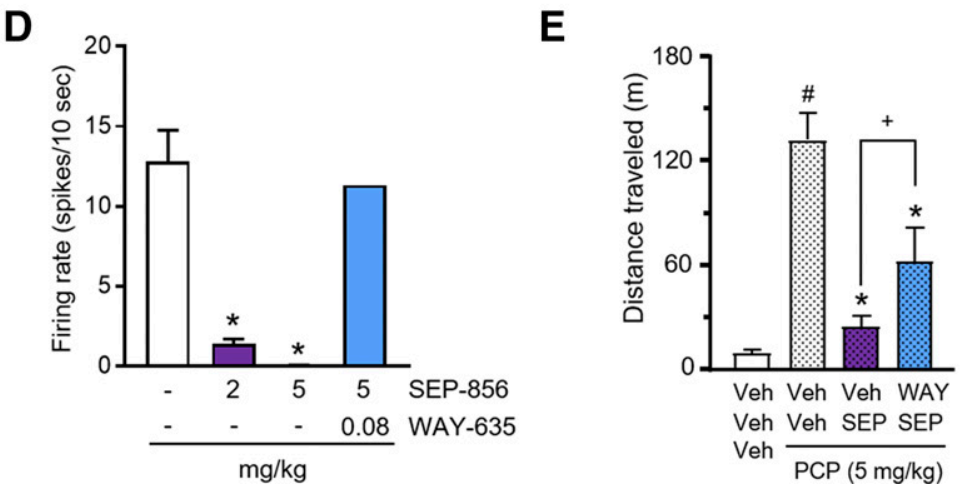

Fig. 8. SEP-856 inhibits firing of DRN in vivo and partially attenuates PCP-induced hyperactivity through 5-HT $1 \mathrm{~A}$ receptors. (A) SEP-856 (2 mg/kg, i.v.) decreased single-unit discharges of DRN neurons in anesthetized Sprague-Dawley rats $(n=2)$. (B) The most significant inhibition was observed during the first 10 minutes after dosing, with discharge rates returned to baseline levels $\sim 20$ minutes later (48-53 minutes after start of recording). (C and D) Neuronal DRN firing rates were completely suppressed by a higher dose of SEP-856 ( $5 \mathrm{mg} / \mathrm{kg}$, i.v., two-tailed $t$ test, $* P<0.05, n=2)$, and this inhibition was subsequently reversed by WAY-100635 $(0.08 \mathrm{mg} / \mathrm{kg} ; n=1)$. (E) Pretreatment of WAY-100635 (1 mg/kg, i.p.) partially attenuated the ability of SEP$856\left(3 \mathrm{mg} / \mathrm{kg}\right.$, p.o.) to reduce PCP-induced hyperactivity in C57BL/6J mice (one-way ANOVA + Tukey's post hoc test, ${ }^{+} P<0.05, * P<0.05 \mathrm{vs}$. Veh/Veh/ PCP, ${ }^{\#} P<0.05$ vs. Veh/Veh/Veh; $n=9$ to 10/group). Abbreviations: WAY-100635 (WAY or WAY-635). Data are shown as mean \pm S.E.M.

\section{Discussion}

Numerous advances have been made in understanding the potential role of receptors other than $\mathrm{D}_{2}$ in contributing to drug efficacy and specific side effects in schizophrenia. Recent antipsychotic drug development has focused on non- $\mathrm{D}_{2}$ targets, including $\mathrm{D}_{1}, \mathrm{D}_{4}, \mathrm{D}_{3}, \mathrm{NMDA}, 5-\mathrm{HT}_{2 \mathrm{~A}}, 5-\mathrm{HT}_{2 \mathrm{C}}, \mathrm{M}_{1}, \mathrm{M}_{4}$, $\mathrm{H}_{3}, \mathrm{NK}_{3}$, and $\sigma$ receptors (Miyamoto et al., 2005; Karam et al., 2010; Girgis et al., 2019). However, to date, no compound lacking $\mathrm{D}_{2}$ receptor blockade has proven effective for any symptom dimension of schizophrenia. Although several non$\mathrm{D}_{2}$ mechanisms, including mGlu2/3 receptor agonism and GlyT1 inhibition, have demonstrated efficacy in nonclinical and clinical proof-of-concept studies, positive results in Phase III clinical trials are still lacking (Marsman et al., 2013; Kinon et al., 2015; Girgis et al., 2019). In this study, we used an in vivo mouse phenotypic screening platform in combination with comprehensive in vitro and in vivo profiling to identify compounds that exhibited behavioral similarity to known antipsychotics but do not act through $\mathrm{D}_{2}$ or $5-\mathrm{HT}_{2 \mathrm{~A}}$ mechanisms. This led to the discovery of SEP-856, a compound that showed potent antipsychotic-like properties without inducing catalepsy. In addition, SEP-856 demonstrated potential antidepressant-like effects, suppressed REM sleep, and modulated firing in a subset of VTA and DRN neurons.

To decipher the molecular mechanism of action (MOA) of SEP-856, its effects were initially studied in panel screens of large numbers of receptors, ion channels, and enzymes. Subsequent studies identified activity at TAAR1, $5-\mathrm{HT}_{1 \mathrm{~A}}, 5-\mathrm{HT}_{1 \mathrm{D}}$, $\alpha_{2 \mathrm{~A}}$, and $\mathrm{D}_{2}$ receptors. Weak partial agonism of $\mathrm{D}_{2}$ receptors $\left(\mathrm{EC}_{50}=8-10 \mu \mathrm{M}, \mathrm{E}_{\max } 24 \%-27 \%\right)$, and some very low-potency antagonism (34\% inhibition at $100 \mu \mathrm{M}$ ), was seen in in vitro assays. It should be noted that this antagonism was assay dependent as, for instance, no antagonist response was seen in the $\beta$-arrestin recruitment assay. Despite this in vitro activity, additional experiments indicated that the MOA of SEP-856 does not include in vivo blockade at $\mathrm{D}_{2}$ given the lack of receptor occupancy in rat and monkey seen at doses/exposures that are efficacious in rodent behavioral assays. Furthermore, the demonstrated central occupancy of $5-\mathrm{HT}_{1 \mathrm{~A}}$ receptors, as well as the partial reversal of PCP-induced hyperactivity in the presence of WAY-100635, indicates that $5-\mathrm{HT}_{1 \mathrm{~A}}$ agonism contributes to the MOA of SEP-856. This was further supported by SEP-856's ability to induce significant inhibitory responses via $5-\mathrm{HT}_{1 \mathrm{~A}}$ receptors in putative serotonergic neurons in the DRN in vitro and in vivo. Notably, the inhibitory response induced in a subset of VTA neurons was mediated, at least in part, via activation of TAAR1, suggesting that SEP-856 modulates firing of putative serotonergic and dopaminergic neurons through distinct mechanisms.

TAAR1 is a GPCR activated by trace amines and expressed in multiple regions of the mammalian brain, including the limbic system, DRN and VTA (Borowsky et al., 2001; Burchett and Hicks, 2006; Lindemann et al., 2008; Rutigliano et al., 2018). Recent studies have extensively characterized TAAR1 functions, elucidating its important role in modulating dopaminergic circuitry and its potential implications in neuropsychiatric disorders (Borowsky et al., 2001; Leo et al., 2014; 
Gainetdinov et al., 2018; Schwartz et al., 2018). Revel et al. (2011) reported the first selective TAAR1 agonist (RO5166017) and demonstrated its inhibitory effects on the firing of dopaminergic and serotonergic neurons. In addition, the antipsychotic-like profile of full and partial TAAR1-selective agonists was shown by their ability to inhibit cocaine and PCP-induced hyperlocomotion in rodents despite their lack of affinity for $\mathrm{D}_{2}$ receptors (Revel et al., 2011, 2012b, 2013). Similarly, SEP-856 was able to block PCP-induced hyperactivity without significantly occupying $\mathrm{D}_{2}$ receptors. Unfortunately, the lack of suitable TAAR1 antagonists prevented direct assessment ofTAAR1's contribution to the antipsychotic-like activity of SEP-856 in vivo.

TAAR1's ability to regulate presynaptic dopaminergic neurotransmission makes it an interesting target for a number of psychiatric disorders (Lindemann et al., 2008; Revel et al., 2011; Leo et al., 2014). Along these lines, TAAR1 agonists have demonstrated efficacy in genetic mouse models of hyperdopaminergia, including DAT knockout (KO) mice and rats (Revel et al., 2011, 2012a,b). The observed effects on dopaminergic signaling presumably occur via functional physical interaction of TAAR 1 with $\mathrm{D}_{2}$ receptors and potentially also with the dopamine transporter (Espinoza et al., 2011; Leo et al., 2014; Harmeier et al., 2015; Leo and Espinoza, 2016). Cell culture studies have shown that TAAR1 is normally located intracellularly but can translocate to the plasma membrane when coexpressed with $\mathrm{D}_{2}$ receptors (Espinoza et al., 2011; Harmeier et al., 2015). The ability of TAAR1 to modulate dopaminergic tone was also demonstrated in TAAR1 KO mice. Under baseline conditions, striatal dopamine release was not altered in $\mathrm{KO}$ animals compared with wild-type controls but was augmented following an amphetamine challenge (Wolinsky et al., 2007; Lindemann et al., 2008). Follow-up work by Leo et al. (2014), using microdialysis and fast-scan cyclic voltammetry, revealed increased levels of dopamine specifically in the nucleus accumbens but not in the dorsal striatum of TAAR1 KO mice (Lindemann et al., 2008). In accordance, TAAR1 agonists have been reported to suppress VTA neuronal firing (Revel et al., 2011) and inhibit electrically-evoked dopamine release (Leo et al., 2014). SEP856 exerted inhibitory effects in VTA neurons, which were likely mediated via activation of TAAR1. Interestingly, the inhibitory response was only observed in half of the recorded cells, pointing to a selective suppression of a subset of VTA neurons by SEP-856. The lack of $\mathrm{D}_{2}$ occupancy, in addition to the inhibitory effects on VTA neuronal firing, potentially suggests modulation of presynaptic dopamine dysfunction by SEP-856. Abnormalities in dopamine synthesis capacity, baseline synaptic dopamine levels, and dopamine release have been reported in schizophrenia patients, and are not targeted by current antipsychotic treatments (Howes et al., 2012; Jauhar et al., 2017; Kim et al., 2017; McCutcheon et al., 2018). Although SEP-856 demonstrated clear inhibitory effects on DRN and VTA neurons, it did not alter dopamine or 5-HT release in the striatum or prefrontal cortex. This could be due to a number of reasons, including the difficulty in detecting potential decreases in neurotransmitter release under baseline conditions using conventional microdialysis. Differential effects of SEP-856 on dopamine and/or serotonin release might primarily be detectable under stimulated conditions (e.g., following electrical, pharmacological, or behavioral challenges) or in a disease context (e.g., hyperdopaminergic state). In contrast, changes in dopaminergic and serotonergic cell firing do not necessarily translate into changes in dopamine/5-HT release (Berke, 2018). For example, dopamine release can be locally controlled by the presynaptic terminals themselves and thus show spatiotemporal patterns independent of cell body spiking (Floresco et al., 1998; Jones et al., 2010; Berke, 2018). In addition, SEP-856 might affect tonic versus phasic dopaminergic firing differentially, which could ultimately result in marked behavioral effects without necessarily altering overall dopamine levels. Additional experiments, applying both microdialysis and fast-scan cyclic voltammetry, will help to further elucidate the effect of SEP-856 on neurotransmitter release and firing kinetics under baseline and stimulated conditions.

In addition to TAAR1-mediated activity, 5- $\mathrm{HT}_{1 \mathrm{~A}}$ agonism was identified as an integral part of the MOA of SEP-856. The $5-\mathrm{HT}_{1 \mathrm{~A}}$ receptor is highly expressed in the DRN, cortex, and limbic forebrain areas (e.g., hippocampus and amygdala), with lower densities detected in the basal ganglia, thalamus, substantia nigra, and VTA (Kia et al., 1996; Ito et al., 1999; De Almeida and Mengod, 2008). In the DRN, $5-\mathrm{HT}_{1 \mathrm{~A}}$ receptors are primarily somatodendritic autoreceptors that function to inhibit neuronal firing. In contrast, they are present as postsynaptic receptors in the hippocampus and amygdala (Celada et al., 2013). Thus, it will be interesting to test whether SEP-856 also acts in an inhibitory fashion in forebrain regions such as the hippocampus or prefrontal cortex.

The serotonergic circuitry has repeatedly been implicated in the pathophysiology of schizophrenia, in part due to the antipsychotic properties of $5-\mathrm{HT}_{2 \mathrm{~A}}$ antagonists (although primarily in combination with $\mathrm{D}_{2}$ blockers). In addition, $5-\mathrm{HT}_{2 \mathrm{C}}$ antagonists and compounds that target both receptors $5-\mathrm{HT}_{2 \mathrm{~A}} / 5-\mathrm{HT}_{2 \mathrm{C}}$ (e.g., ritanserin, vabicaserin, mianserin, SR46349B, etc.) have demonstrated some efficacy in schizophrenia (Girgis et al., 2019). Although evidence exists for the therapeutic efficacy of $5-\mathrm{HT}_{1 \mathrm{~A}}$ agonists in depression and anxiety, less is known about the potential contribution of these receptors to schizophrenia. Postmortem (Burnet et al., 1996, 1997; Simpson et al., 1996; Sumiyoshi et al., 1996) and neuroimaging studies (Kasper et al., 2002; Tauscher et al., 2002) have revealed alterations in $5-\mathrm{HT}_{1 \mathrm{~A}}$ receptor density in the cortex and amygdala of schizophrenic patients (Yasuno et al., 2004). Evidence in rodent models indicates that the activation of $5-\mathrm{HT}_{1 \mathrm{~A}}$ receptors prevents EPS induced by $\mathrm{D}_{2}$ receptor blockade, modulates dopaminergic neurotransmission in the frontal cortex, positively influences mood, and attenuates NMDA receptor antagonist-induced cognitive and social interaction deficits (Newman-Tancredi, 2010; Celada et al., 2013). In addition, a number of compounds that combine partial agonism at $5-\mathrm{HT}_{1 \mathrm{~A}}$ receptors with antagonism (or partial agonism) at $\mathrm{D}_{2}$ receptors (e.g., aripiprazole, perospirone, lurasidone, cariprazine, PF-217830, F-97013-GD, F-15063, and bifeprunox) appear to provide therapeutic benefits against a broader range of schizophrenia symptoms (NewmanTancredi, 2010; Celada et al., 2013).

Interestingly, earlier work demonstrated that modulation of TAAR 1 activity via the selective agonist RO5166017 increases the potency of $5-\mathrm{HT}_{1 \mathrm{~A}}$ partial agonists and alters the desensitization rate at the $5-\mathrm{HT}_{1 \mathrm{~A}}$ autoreceptors in the $\mathrm{DRN}$ 
(Revel et al., 2011). This can occur by direct interaction of TAAR1 and $5-\mathrm{HT}_{1 \mathrm{~A}}$, or by favoring interactions with the GPCR desensitization machinery. Consequently, Revel et al. (2011) proposed that cotreatment with a TAAR1 agonist might improve therapeutic efficacy of classic antidepressants, providing further support for compounds with dual $5-\mathrm{HT}_{1 \mathrm{~A}} /$ TAAR1 activity in the treatment of psychosis and mood. Notably, TAAR1 agonists and many antidepressants (especially those with $5-\mathrm{HT}_{1 \mathrm{~A}}$ activity) exert REM sleep suppression, which is not observed for most $\mathrm{D}_{2}$-based antipsychotics (Tribl et al., 2013; Wichniak et al., 2017; Goonawardena et al., 2019). Thus, the robust REM suppression observed with SEP-856 could result from synergistic action on TAAR1 and $5-\mathrm{HT}_{1 \mathrm{~A}}$ receptors. However, agonism at TAAR1 and 5$\mathrm{HT}_{1 \mathrm{~A}}$ receptors might only partially contribute to SEP-856's MOA, with other (possibly not yet identified) targets likely playing key roles as well.

Although this work made use of multiple pharmacological rodent models and assays, it is important to mention that no animal model is, or ever will be, truly reflective of the underlying disease etiology of schizophrenia. Nevertheless, certain models serve as important investigational tools and are useful in the development of novel treatments, especially when the goals for a specific model and/or approach are clearly defined (Nestler and Hyman, 2010). Our goal was to identify a novel MOA for the treatment of schizophrenia by focusing on a desired clinical outcome-the combination of antipsychotic efficacy and lack of $\mathrm{D}_{2}$-mediated side effects (e.g., EPS and endocrine effects). Ultimately, proof-of-concept studies in humans are required to determine whether preclinical findings will translate into therapeutic efficacy. SEP-856 is currently being evaluated for the treatment of schizophrenia in randomized, controlled clinical trials.

In summary, the approach used in this work represents an alternative to target-driven drug discovery as it relied on in vivo phenotypic and in in vitro (anti-target) screening, followed by subsequent verification in putative animal models of schizophrenia. Accordingly, the MOA of SEP856 has not been fully elucidated. However, the selective agonism of TAAR1 and $5-\mathrm{HT}_{1 \mathrm{~A}}$, in addition to the lack of $\mathrm{D}_{2} / 5-\mathrm{HT}_{2 \mathrm{~A}}-$ mediated efficacy, has the potential to translate into a significantly improved safety profile compared with available therapies, while still maintaining antipsychotic efficacy across a broad array of symptoms. Based on its unique MOA and preclinical profile in animals, SEP-363856 represents a promising candidate for the treatment of schizophrenia and potentially other neuropsychiatric disorders.

\section{Acknowledgments}

This manuscript is dedicated to the memory of a beloved colleague, Dr. Una C. Campbell.

\section{Authorship Contributions}

Participated in research design: Jones, Hopkins, Lew, Shao, J.E. Campbell, Spear, Large, U.C. Campbell, Hanania, Leahy, Koblan.

Conducted experiments: Jones, Lew, U.C. Campbell, J.E. Campbell, Hanania.

Performed data analyses: Dedic, Jones, Hopkins, Lew, J.E. Campbell, Large, U.C. Campbell, Hanania.

Wrote or contributed to the writing of the manuscript: Dedic, Jones, Hopkins, Lew, Large, Hanania, Koblan.

\section{References}

Alexandrov V, Brunner D, Hanania T, and Leahy E (2015) High-throughput analysis of behavior for drug discovery. Eur $J$ Pharmacol 750:82-89.

Belema M and Meanwell NA (2014) Discovery of daclatasvir, a pan-genotypic hepatitis $\mathrm{C}$ virus NS5A replication complex inhibitor with potent clinical effect. $J$ Med Chem 57:5057-5071.

Berke JD (2018) What does dopamine mean? Nat Neurosci 21:787-793.

Black SW, Schwartz MD, Chen TM, Hoener MC, and Kilduff TS (2017) Trace amineassociated receptor 1 agonists as narcolepsy therapeutics. Biol Psychiatry $\mathbf{8 2}$ 623-633.

Borowsky B, Adham N, Jones KA, Raddatz R, Artymyshyn R, Ogozalek KL, Durkin MM, Lakhlani PP, Bonini JA, Pathirana S, et al. (2001) Trace amines: identification of a family of mammalian G protein-coupled receptors. Proc Natl Acad Sci USA 98:8966-8971.

Burchett SA and Hicks TP (2006) The mysterious trace amines: protean neuromodulators of synaptic transmission in mammalian brain. Prog Neurobiol $\mathbf{7 9}$ 223-246.

Burnet PW, Eastwood SL, and Harrison PJ (1996) 5-HT1A and 5-HT2A receptor mRNAs and binding site densities are differentially altered in schizophrenia. Neurop 15:442-455.

Burnet PWJ, Eastwood SL, and Harrison PJ (1997) [3H]WAY-100635 for 5-HT1A receptor autoradiography in human brain: a comparison with [3H]8-OH-DPAT and demonstration of increased binding in the frontal cortex in schizophrenia. Neurochem Int 30:565-574.

Celada P, Bortolozzi A, and Artigas F (2013) Serotonin 5-HT1A receptors as targets for agents to treat psychiatric disorders: rationale and current status of research. CNS Drugs 27:703-716.

Charpentier P, Gailliot P, and Jacob R (1952) Recherches sur les diméthylaminopropyl-N phénothiazines substituées. Comptes rendus Acad Sci 235:59-60.

Christian SL and Berry MD (2018) Trace amine-associated receptors as novel therapeutic targets for immunomodulatory disorders. Front Pharmacol 9:680.

de Almeida J and Mengod G (2008) Serotonin 1A receptors in human and monkey prefrontal cortex are mainly expressed in pyramidal neurons and in a GABAergic interneuron subpopulation: implications for schizophrenia and its treatment. $J$ Neurochem 107:488-496.

Espinoza S, Salahpour A, Masri B, Sotnikova TD, Messa M, Barak LS, Caron MG, and Gainetdinov RR (2011) Functional interaction between trace amine-associated receptor 1 and dopamine D2 receptor. Mol Pharmacol 80:416-425.

Floresco SB, Yang CR, Phillips AG, and Blaha CD (1998) Basolateral amygdala stimulation evokes glutamate receptor-dependent dopamine efflux in the nucleus accumbens of the anaesthetized rat. Eur J Neurosci 10:1241-1251.

Gainetdinov RR, Hoener MC, and Berry MD (2018) Trace amines and their receptors. Pharmacol Rev 70:549-620.

Geyer MA, Krebs-Thomson K, Braff DL, and Swerdlow NR (2001) Pharmacological studies of prepulse inhibition models of sensorimotor gating deficits in schizophrenia: a decade in review. Psychopharmacology (Berl) 156:117-154.

Girgis RR, Zoghbi AW, Javitt DC, and Lieberman JA (2019) The past and future of novel, non-dopamine-2 receptor therapeutics for schizophrenia: a critical and comprehensive review. J Psychiatr Res 108:57-83.

Goonawardena AV, Morairty SR, Dell R, Orellana GA, Hoener MC, Wallace TL, and Kilduff TS (2019) Trace amine-associated receptor 1 agonism promotes wakefulness without impairment of cognition in Cynomolgus macaques. Neuropsychopharmacology 44:1485-1493.

Harmeier A, Obermueller S, Meyer CA, Revel FG, Buchy D, Chaboz S, Dernick G, Wettstein JG, Iglesias A, Rolink A, et al. (2015) Trace amine-associated receptor 1 activation silences GSK3 $\beta$ signaling of TAAR1 and D2R heteromers. Eur Neuropsychopharmacol 25:2049-2061.

Howes OD, Kambeitz J, Kim E, Stahl D, Slifstein M, Abi-Dargham A, and Kapur S (2012) The nature of dopamine dysfunction in schizophrenia and what this means for treatment. Arch Gen Psychiatry 69:776-786.

Insel TR (2010) Rethinking schizophrenia. Nature 468:187-193.

Ito H, Halldin C, and Farde L (1999) Localization of 5-HT1A receptors in the living human brain using [carbonyl-11C]WAY-100635: PET with anatomic standardization technique. J Nucl Med 40:102-109.

Jauhar S, Veronese M, Rogdaki M, Bloomfield M, Natesan S, Turkheimer F, Kapur $\mathrm{S}$, and Howes OD (2017) Regulation of dopaminergic function: an $\left[{ }^{18} \mathrm{~F}\right]-\mathrm{DOPA}$ PET apomorphine challenge study in humans. Transl Psychiatry 7:e1027.

Jones CA, Watson DJ, and Fone KC (2011) Animal models of schizophrenia. $\mathrm{Br}$ J Pharmacol 164:1162-1194.

Jones JL, Day JJ, Aragona BJ, Wheeler RA, Wightman RM, and Carelli RM (2010) Basolateral amygdala modulates terminal dopamine release in the nucleus accumbens and conditioned responding. Biol Psychiatry 67:737-744.

Karam CS, Ballon JS, Bivens NM, Freyberg Z, Girgis RR, Lizardi-Ortiz JE, Markx S, Lieberman JA, and Javitch JA (2010) Signaling pathways in schizophrenia: emerging targets and therapeutic strategies. Trends Pharmacol Sci 31:381-390.

Kasper S, Tauscher J, Willeit M, Stamenkovic M, Neumeister A, Küfferle B, Barnas C, Stastny J, Praschak-Rieder N, Pezawas L, et al. (2002) Receptor and transporter imaging studies in schizophrenia, depression, bulimia and Tourette's disorder-implications for psychopharmacology. World J Biol Psychiatry 3:133-146.

Kia HK, Miquel MC, Brisorgueil MJ, Daval G, Riad M, El Mestikawy S, Hamon M, and Vergé D (1996) Immunocytochemical localization of serotonin1A receptors in the rat central nervous system. J Comp Neurol 365:289-305.

Kim E, Howes OD, Veronese M, Beck K, Seo S, Park JW, Lee JS, Lee YS, and Kwon JS (2017) Presynaptic dopamine capacity in patients with treatment-resistant schizophrenia taking clozapine: an $\left[{ }^{18} \mathrm{~F}\right] \mathrm{DOPA}$ PET study. Neuropsychopharmacology 42:941-950.

Kinon BJ, Millen BA, Zhang L, and McKinzie DL (2015) Exploratory analysis for a targeted patient population responsive to the metabotropic glutamate $2 / 3$ receptor agonist pomaglumetad methionil in schizophrenia. Biol Psychiatry 78:754-762. 
Laborit H, Huguenard P, and Alluaume R (1952) Un nouveau stabilisateur végétatif; le 4560 RP. Presse Med 60:206-208.

Lehmann HE and Ban TA (1997) The history of the psychopharmacology of schizophrenia. Can J Psychiatry 42:152-162.

Leo D and Espinoza S (2016) Trace Amine-Associated Receptor 1 Modulation of Dopamine System, Elsevier.

Leo D, Mus L, Espinoza S, Hoener MC, Sotnikova TD, and Gainetdinov RR (2014) Taar1-mediated modulation of presynaptic dopaminergic neurotransmission: role of D2 dopamine autoreceptors. Neuropharmacology 81:283-291.

Lieberman JA, Stroup TS, McEvoy JP, Swartz MS, Rosenheck RA, Perkins DO, Keefe RS, Davis SM, Davis CE, Lebowitz BD, et al.; Clinical Antipsychotic Trials of Intervention Effectiveness (CATIE) Investigators (2005) Effectiveness of antipsychotic drugs in patients with chronic schizophrenia. N Engl J Med 353:1209-1223.

Lindemann L, Meyer CA, Jeanneau K, Bradaia A, Ozmen L, Bluethmann H, Bettler B, Wettstein JG, Borroni E, Moreau J-L, et al. (2008) Trace amine-associated receptor 1 modulates dopaminergic activity. J Pharmacol Exp Ther 324:948-956.

Marsman A, van den Heuvel MP, Klomp DWJ, Kahn RS, Luijten PR, and Hulshoff Pol HE (2013) Glutamate in schizophrenia: a focused review and meta-analysis of ${ }^{1}$ H-MRS studies. Schizophr Bull 39:120-129.

Martin LP, Jackson DM, Wallsten C, and Waszczak BL (1999) Electrophysiological comparison of 5-hydroxytryptamine1A receptor antagonists on dorsal raphe cell firing. J Pharmacol Exp Ther 288:820-826.

McCutcheon R, Beck K, Jauhar S, and Howes OD (2018) Defining the locus of dopaminergic dysfunction in schizophrenia: a meta-analysis and test of the mesolimbic hypothesis. Schizophr Bull 44:1301-1311.

Meyer-Lindenberg A (2010) From maps to mechanisms through neuroimaging of schizophrenia. Nature 468:194-202.

Miyamoto S, Duncan GE, Marx CE, and Lieberman JA (2005) Treatments for schizophrenia: a critical review of pharmacology and mechanisms of action of antipsychotic drugs. Mol Psychiatry 10:79-104.

Miyamoto S, Leipzig JN, Lieberman JA, and Duncan GE (2000) Effects of ketamine, MK-801, and amphetamine on regional brain 2-deoxyglucose uptake in freely moving mice. Neuropsychopharmacology 22:400-412.

Moffat JG, Vincent F, Lee JA, Eder J, and Prunotto M (2017) Opportunities and challenges in phenotypic drug discovery: an industry perspective. Nat Rev Drug Discov 16:531-543.

Nestler EJ and Hyman SE (2010) Animal models of neuropsychiatric disorders. Nat Neurosci 13:1161-1169.

Newman-Tancredi A (2010) The importance of 5-HT1A receptor agonism in antipsychotic drug action: rationale and perspectives. Curr Opin Investig Drugs 11: 802-812.

Porsolt RD, Le Pichon M, and Jalfre M (1977) Depression: a new animal model sensitive to antidepressant treatments. Nature 266:730-732.

Ratajczak P, Wozniak A, and Nowakowska E (2013) Animal models of schizophrenia: developmental preparation in rats. Acta Neurobiol Exp (Warsz) 73:472-484.

Revel FG, Meyer CA, Bradaia A, Jeanneau K, Calcagno E, André CB, Haenggi M, Miss MT, Galley G, Norcross RD, et al. (2012a) Brain-specific overexpression of trace amine-associated receptor 1 alters monoaminergic neurotransmission and decreases sensitivity to amphetamine. Neuropsychopharmacology 37:2580-2592.

Revel FG, Moreau J-L, Gainetdinov RR, Bradaia A, Sotnikova TD, Mory R, Durkin S, Zbinden KG, Norcross R, Meyer CA, et al. (2011) TAAR1 activation modulates monoaminergic neurotransmission, preventing hyperdopaminergic and hypoglutamatergic activity. Proc Natl Acad Sci USA 108:8485-8490.

Revel FG, Moreau JL, Gainetdinov RR, Ferragud A, Velázquez-Sánchez C, Sotnikova TD, Morairty SR, Harmeier A, Groebke Zbinden K, Norcross RD, et al. (2012b) Trace amine-associated receptor 1 partial agonism reveals novel paradigm for neuropsychiatric therapeutics. Biol Psychiatry 72:934-942.
Revel FG, Moreau JL, Pouzet B, Mory R, Bradaia A, Buchy D, Metzler V, Chaboz S, Groebke Zbinden K, Galley G, et al. (2013) A new perspective for schizophrenia: TAAR1 agonists reveal antipsychotic- and antidepressant-like activity, improve cognition and control body weight. Mol Psychiatry 18:543-556.

Roberds SL, Filippov I, Alexandrov V, Hanania T, and Brunner D (2011) Rapid, computer vision-enabled murine screening system identifies neuropharmacological potential of two new mechanisms. Front Neurosci 5:103.

Rutigliano G, Accorroni A, and Zucchi R (2018) The case for TAAR1 as a modulator of central nervous system function. Front Pharmacol 8:987.

Samara MT, Dold M, Gianatsi M, Nikolakopoulou A, Helfer B, Salanti G, and Leucht S (2016) Efficacy, acceptability, and tolerability of antipsychotics in treatment-resistant schizophrenia: a network meta-analysis. JAMA Psychiatry 73:199-210

Schwartz MD, Black SW, Fisher SP, Palmerston JB, Morairty SR, Hoener MC, and Kilduff TS (2017) Trace amine-associated receptor 1 regulates wakefulness and EEG spectral composition. Neuropsychopharmacology 42:1305-1314.

Schwartz MD, Canales JJ, Zucchi R, Espinoza S, Sukhanov I, and Gainetdinov RR (2018) Trace amine-associated receptor 1: a multimodal therapeutic target for neuropsychiatric diseases. Expert Opin Ther Targets 22:513-526.

Shao L, Campbell UC, Fang QK, Powell NA, Campbell JE, Jones PG, Hanania T, Alexandrov V, Morganstern I, Sabath E, et al. (2016) In vivo phenotypic drug discovery: applying a behavioral assay to the discovery and optimization of novel antipsychotic agents. MedChem Comm 7:1093-1101.

Simpson MDC, Lubman DI, Slater P, and Deakin JFW (1996) Autoradiography with $[3 \mathrm{H}] 8-\mathrm{OH}-\mathrm{DPAT}$ reveals increases in 5 -HT(1A) receptors in ventral prefrontal cortex in schizophrenia. Biol Psychiatry 39:919-928.

Steeds H, Carhart-Harris RL, and Stone JM (2015) Drug models of schizophrenia. Ther Adv Psychopharmacol 5:43-58.

Sumiyoshi T, Stockmeier CA, Overholser JC, Dilley GE, and Meltzer HY (1996) Serotonin1A receptors are increased in postmortem prefrontal cortex in schizophrenia. Brain Res 708:209-214.

Swinney DC and Anthony J (2011) How were new medicines discovered? Nat Rev Drug Discov 10:507-519.

Tauscher J, Kapur S, Verhoeff NP, Hussey DF, Daskalakis ZJ, Tauscher-Wisniewski S, Wilson AA, Houle S, Kasper S, and Zipursky RB (2002) Brain serotonin 5$\mathrm{HT}(1 \mathrm{~A})$ receptor binding in schizophrenia measured by positron emission tomography and [11C]WAY-100635. Arch Gen Psychiatry 59:514-520.

Tribl GG, Wetter TC, and Schredl M (2013) Dreaming under antidepressants: a systematic review on evidence in depressive patients and healthy volunteers. Sleep Med Rev 17:133-142.

Wichniak A, Wierzbicka A, Walęcka M, and Jernajczyk W (2017) Effects of antidepressants on sleep. Curr Psychiatry Rep 19:63.

Wilson CA, Koenig JI, and Psychiatric M (2015) Social interaction and social withdrawal in rodents as readouts for investigating the negative symptoms of schizophrenia. Eur Neuropsychopharmacol 24:759-773.

Wolinsky TD, Swanson CJ, Smith KE, Zhong H, Borowsky B, Seeman P, Branchek T, and Gerald CP (2007) The trace amine 1 receptor knockout mouse: an animal model with relevance to schizophrenia. Genes Brain Behav 6:628-639.

Yasuno F, Suhara T, Ichimiya T, Takano A, Ando T, and Okubo Y (2004) Decreased 5-HT1A receptor binding in amygdala of schizophrenia. Biol Psychiatry 55:439-444.

Address correspondence to: Dr. Kenneth S. Koblan, Sunovion Pharmaceuticals, 84 Waterford Drive, Marlborough, MA 01752. E-mail: Kenneth.Koblan@ Sunovion.com 